\author{
UNIVERSIDADE DE SÃO PAULO \\ FACULDADE DE ECONOMIA, ADMINISTRAÇÃO E CONTABILIDADE \\ DEPARTAMENTO DE ECONOMIA \\ PROGRAMA DE PÓS-GRADUAÇÃO EM ECONOMIA
}

\title{
Do people vote for education? Evidence from Brazilian municipal elections
}

As pessoas votam em educação?

Evidência das eleições municipais brasileiras

Matheus de Mello de Assunção

Orientadora: Prof. Dr. Fernanda Gonçalves de La Fuente Estevan

São Paulo

2016 
Prof. Dr. Marco Antonio Zago

Reitor da Universidade de São Paulo

Prof. Dr. Adalberto Américo Fischmann

Diretor da Faculdade de Economia, Administração e Contabilidade

Prof. Dr. Hélio Nogueira da Cruz

Chefe do Departamento de Economia

Prof. Dr. Márcio Issao Nakane

Coordenador do Programa de Pós-Graduação em Economia 
MATHEUS DE MELLO DE ASSUNÇÃO

\section{Do people vote for education? Evidence from}

\section{Brazilian municipal elections}

As pessoas votam em educação?

Evidência das eleições municipais brasileiras

Dissertação apresentada ao Departamento de Economia da Faculdade de Economia, Administração e Contabilidade da Universidade de São Paulo como requisito parcial para a obtenção do título de Mestre em Ciências.

Orientadora: Prof. Dr. Fernanda Gonçalves de La Fuente Estevan

\section{Versão Corrigida}

(versão original disponível na Biblioteca da Faculdade de Economia, Administração e Contabilidade)

São Paulo 
FICHA CATALOGRÁFICA

Elaborada pela Seção de Processamento Técnico do SBD/FEA/USP

Assunção, Matheus de Mello de

As pessoas votam em educação ? evidência das eleições muniCipais brasileiras / Matheus de Mello de Assunção. - São Paulo, 2016.

$56 \mathrm{p.}$

Dissertação (Mestrado) - Universidade de São Paulo, 2016.

Orientador: Fernanda Gonçalves de La Fuente Estevan.

1. Educação escolar básica 2. Votação 3. Fundo público I. Universidade de São Paulo. Faculdade de Economia, Administração e e Contabilidade. II. Título.

$\mathrm{CDD}-370$ 


\section{Acknowledgements}

Gostaria inicialmente de agradecer o apoio prestado pela CAPES e pela Fundação de Amparo à Pesquisa do Estado de São Paulo (FAPESP), a última por meio do processo $n^{\text {o } 2015 / 20307-6 . ~}$

Agradeço aos professores Enlison Mattos, Marcos Nakaguma, Maurício Bugarin, Raphael Corbi e Ricardo Madeira, cujos comentários tanto enriqueceram este trabalho. Agradeço também aos participantes do Political Economy Colloquium de Princeton por todas as críticas e ao professor Thomas Fujiwara pela inestimável oportunidade. Agradeço, principalmente, à minha orientadora, Fernanda Estevan, pela perene disponibilidade e valioso direcionamento. Sem você este trabalho não seria metade do que acabou sendo.

Agradeço à minha turma de mestrado. Sem dúvida nenhuma o maior benefício deste curso foi ter o privilégio de aprender e dividir momentos com vocês. À Luiza pelo caderno, ao Luan pelo Stata, ao Marcelo pelas discussões, ao Tiago pelos cafés, trabalhos e risadas, e ao Fernando pelo apoio e cada hoagie que comemos. A São Paulo, pelos irmãos que me deu: Assaf, Dito, Rafa e Thiago. A garoa é fria, mas os corações esquentam. Agradeço ao Gabriel Corrêa e à Ana Paula pelo desprendimento e ajuda com a base de dados e os documentos do BEPE. Ao Thierry pela eterna amizade e valioso apoio computacional.

Agradecimentos especiais a Raphael Bruce, Pedro Feitosa, Francisco Espinosa, Paulo Lins e Deborah Seabra. Ao Bruce por conselhos inestimáveis. Eu não teria ido a Princeton sem você. Ao Feitosa, por sempre tratar os problemas dos amigos como "nossos". Essa dissertação é nossa. Ao Francisco pelo apoio constante e amizade. Você foi a minha família em São Paulo. À Deborah e ao Paulo, por estarem lá e me darem ainda mais certeza de que quem tem amigos tem tudo.

Agradeço, acima de tudo a meus irmãos, Flávia e Henrique, meus pais, Lisiane e Flávio, e à minha namorada e companheira, Verônica. Vocês engrandecem minha alma e, como disse $\mathrm{O}$ poeta fazem tudo valer à pena.

Obrigado. 

"Education had been a great gift for him [Malala's father]. He believed that lack of education was the root of all Pakistan's problems. Ignorance allowed politicians to fool people and bad administrators to be reelected. He believed schooling should be available for all, rich and poor, boys and girls. The school that my father dreamed of would have desks and a library, computers, bright posters on the walls and, most important, washrooms." 



\section{Resumo}

A educação básica é largamente citada na literatura em economia como fator essencial para o desenvolvimento de um país. Além disso, pelas externalidades que gera, ela é tida como serviço cuja oferta social ótima exige financiamento ou provisão pública. No Brasil, assim como em outros países, a educação básica é constitucionalmente estabelecida como de responsabilidade de estados e municípios. A demanda dos eleitores por educação, entretanto, é pouco conhecida. Este trabalho procura preencher essa lacuna estimando o impacto de uma variação nos gastos municipais com educação básica nas chances de reeleição de um prefeito. Para isso, nós usamos como variação as transferências federais do Fundo de Manutenção e Desenvolvimento do Ensino Fundamental e de Valorização do Magistério (FUNDEF). Além disso, avalia possíveis canais pelos quais os gastos podem trazer retorno político tais como nível de formação de professores e infraestrutura das escolas.

Palavras-chaves: Educação Escolar Básica, Votação, Fundos Públicos. 


\section{Abstract}

Basic education is widely cited in the literature in economics as an essential factor to the development of a country. Moreover, by the externalities it generates, it is seen as a service whose optimal supply requires public financing or provision. In Brazil, as in other countries, basic education is constitutionally established as responsibility of states and municipalities. The demand of voters for education, however, is unknown. This paper seeks to fill this gap by estimating the impact of a change in municipal spending on basic education in the reelection chances of a mayor. For that, it uses as variation the federal transfers from the Fund for the Maintenance and Development of Fundamental Education and Valuing of Teachers (FUNDEF). In addition, it evaluates possible channels through which spending can bring political returns such as level of teacher training and infrastructure of schools.

Key-words: Basic School Education, Voting, Public Fund. 


\section{List of Tables}

Table 1 - Summary statistics . . . . . . . . . . . . . . . 28

Table 2 - Summary statistics by incumbent mayor running or not for reelection . 29

Table 3 - FUNDEF instrumented by simulated FUNDEF97: First stage . . . . . . 34

Table 4 - 2SLS estimates of FUNDEF's impact on education expenditure 1998-2000 36

Table 5 - 2SLS estimates of FUNDEF's impact on other federal and state transfers 38

Table 6 - 2SLS estimates of FUNDEF's impact on municipal expenditures . . . . 39

Table 7 - 2SLS estimates of FUNDEF impact instrumented by simulated FUN-

DEF97 impact effect on an incumbent mayor chances of reelection in

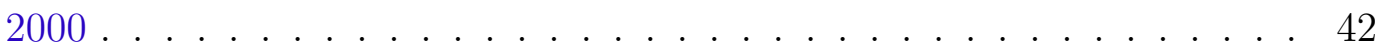

Table 8 - 2SLS estimates of FUNDEF impact instrumented by simulated FUNDEF97 impact effects on an incumbent party coalition chances of reelection in $2000 \ldots \ldots$. . . . . . . . . . . . . . . . . . 4 44

Table 9 - 2SLS estimates of FUNDEF's impact on school quality: class size and teachers education . . . . . . . . . . . . . . . . 46

Table 10 - 2SLS estimates of FUNDEF's impact on school quality: school infrastructure 47

Table 11 - 2SLS estimates of FUNDEF's impact on school quality: school infrastructure - Incumbent mayors of net recipient municipalities . . . . . . 48

Table 12 - 2SLS estimates of FUNDEF's impact on school quality: school infrastructure - Incumbent mayors of net recipient municipalities . . . . . . . 49

Table 13 - 2SLS estimates of FUNDEF's impact on municipal expenditures 1998,

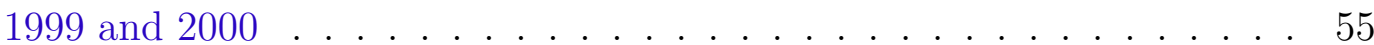

Table 14 - OLS estimates of Impact of FUNDEF97 on FUNDEF . . . . . . . . 56

Table 15 - 2SLS estimates of FUNDEF's impact on school quality: school infrastructure - Incumbent party coalition . . . . . . . . . . . . . . 57

Table 16 - 2SLS estimates of FUNDEF's impact on school quality: school infrastructure - Incumbent party coalition . . . . . . . . . . . . . 58 


\section{Contents}

1 Introduction . . . . . . . . . . . . . . . 13

2 Related Literature $\ldots \ldots \ldots \ldots \ldots \ldots$

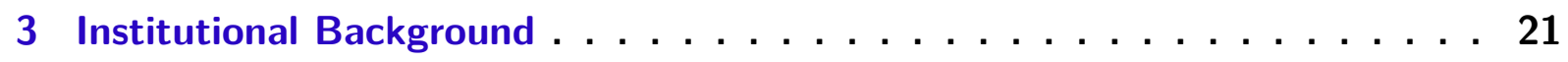

4 Data . . . . . . . . . . . . . . . . . . 25

5 Empirical Strategy $\ldots \ldots \ldots \ldots \ldots \ldots \ldots \ldots \ldots \ldots \ldots$

6 FUNDEF's impact on municipal expenditures . . . . . . . . . . 35

6.0.1 FUNDEF effects on education expenditures . . . . . . . . 35

6.0.2 FUNDEF effects on other expenditures . . . . . . . . . 37

7 Main Results . . . . . . . . . . . . . . . . 41

7.1 FUNDEF effects on reelection $\ldots \ldots \ldots \ldots \ldots \ldots$

7.1 .1 Mayor's reelection . . . . . . . . . . . . . . . . . 41

7.1 .2 Party coalition's reelection . . . . . . . . . . . . . . 43

7.2 FUNDEF effects on school quality . . . . . . . . . . . 45

8 Concluding Remarks $\ldots \ldots \ldots \ldots \ldots \ldots$

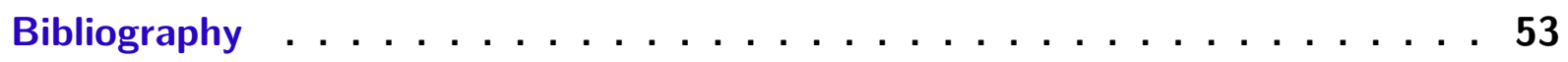

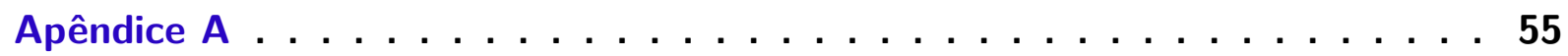

8.1 FUNDEF's impact on other expenditures . . . . . . . . . . 55

8.2 FUNDEF impact instrumented by simulated FUNDEF97 impact: First stage 56

8.3 FUNDEF's impact on school quality for municipalities where the incumbent party coalition ran for reelection . . . . . . . . . . . 57 


\section{Introduction}

Since the seminal work of Romer (1990), a growing literature in economics has been studying the importance of human capital for growth and economic development. The main form of human capital production is formal education, which can be divided into basic (comprised of primary and secondary education) and higher education. Among these different educational levels, many papers highlight the impact of basic education in the generation of human capital (KIMKO; HANUSHEK, 2000; BARBOSA FILHO; PESSÔA, 2009), since its outputs serve as inputs to other educational levels, thus producing a larger effect.

This work analyzes the electoral effect of education expenditures. More specifically it studies the variation in mayors' chances of reelection caused by the variation in municipal education spending by the introduction of an education funding reform called FUNDEF. How do voters respond to a change in education spending? Does it increase the mayor's probability of reelection?

In Brazil, as in many other countries, there is public education provision for primary, secondary and higher levels. The 1988 Constitution provides in Article 208 that basic education is compulsory from 4 to 17 years and it must be publicly provided free of charge. ${ }^{1}$ It also states that municipalities will be in charge of kindergarten, primary and low secondary education and states and Federal District of primary and secondary education.

In recent years, primary education was almost universalized, with nearly all children in school age being at school. Nevertheless, empirical evidence indicates that the quality of education in Brazil is poor and its indicators are well below those of developed countries (VELOSO, 2009). There is room for improvement in educational provision and, since it is already widely available, these improvements would be fundamentally in education quality.

One would expect, therefore, that given these educational shortages (in quality) and the positive returns education generates, both at social and individual levels, individuals

1 Text given by Constitutional Amendment No. 59, 2009 
to demand better education. Since education is largely supplied by the government and, in the case of basic education, by the states and municipalities, citizens should express these preferences through votes in the municipal and state elections.

Basic education provision is an important function of Brazilian municipal administrators both by the significant portion of the resources allocated to it as by its political and popular appeal (SAKURAI, 2009). Thus, one can assume that politicians seek to invest in education to please voters and these reward politicians to do so. Or, if spending was higher than the level preferred by the voters, that the politicians will be penalized by an increase or rewarded by a reduction in spending.

The work empirically analyzes the impact of a change in educational provision in a candidate reelection probability using Brazilian municipal data. It intends to assess the perception of voters to a variation in spending on education, or, more directly, the electoral impact that a shock in educational provision may have in a given municipality. Additionally it investigates possible channels by which education expenditures could impact reelection chances of incumbent mayors.

The paper uses the implementation of fiscal transfers from $\mathrm{FUNDEF}^{2}$ a funding reform that caused variation in educational spending. The fund, implemented in 1998, had as its main objective to improve the distribution of resources for education. It was formed with $15 \%$ of the global revenues of states and municipalities and redistributed resources among them according to the number of students enrolled in primary school in the previous year.

I argue that the fund's transfers can be treated as a source of exogenous variation in education expenditures under some conditions. The approach is similar to that of Estevan (2014), who measured the fund impact on school choice. The use of the fund transfers has as its main objective to eliminate the endogeneity of changes in education spending, using the fact that the fund transfers are not subject to municipalities choices.

2 Fund for Maintenance and Development of Fundamental Education and Valuing of Teacher (FUNDEF) was established by Constitutional Amendment No. 14 of September 1996 and regulated by Law No. 9424 of 24 December of that year, and by Decree No. 2264, June 1997 
Making use of a FUNDEF's impact variable we examine the election results of the incumbents in the 2000 municipal elections, the first following the implementation of the fund. The intention is to assess the impact of the fund transfers and their shock on education expenditures on the electoral result of the mayors of the affected municipalities. Furthermore, the fund transfers are used to estimate the impact that education expenditures could have had in variables related to school quality such as teachers' education and infrastructure items in schools.

The use of constitutional transfers, however, generates an additional problem. If voters are fully informed about the origin of the funds, the federal government in this case, they will not reward/penalize the municipal administration by a variation in the budget arising from such transfers, the determination of which comes from higher levels of government. Rational voters with complete information should not take into account constitutional federal funds in municipal elections.

In spite of that, as argued by Litschig and Morrison (2009), it is unlikely that voters are fully informed about the source of funds used by the public administration. Such voters may reward local politicians based on improvements financed by central governments. The authors studied the effect of federal transfers in mayors' reelection chances in the Brazilian 1988 elections and found significant positive results for mayors not aligned to the central government, then associated with the recently ended authoritarian regime.

Although the funding reform was imposed on municipalities, some degree of potential manipulation in some of the components of the fund still remained. Mayors could boost the number of enrolled students and increase the fund net transfers. Additionally, an unobserved macroeconomic variable could affect tax revenue (and therefore FUNDEF) and election chances. Therefore there is some chance of remaining endogeneity. To address this issue we make use of an exogenous simulated variable following Kosec (2011). Briefly, we estimate the impact of the actual fund transfers instrumented by the hypothetical fund transfers, that reduce the possibility of manipulation, on the chances of reelection. Those hypothetical transfers are calculated using enrollment and revenue data from 1997 and 
FUNDEF rule. They amount to what would the net transfers be if FUNDEF was in place a year before.

Moreover, some budget reallocation by the mayors could not be excluded. As we present in the identification section, there were changes in other expenditures related to the fund transfers. This does not allow us to interpret de results as an education-only impact. Second order effects in other expenditures (specially transport) cannot be ruled out. Therefore, the results have to be interpreted as changes in education expenditure with potential budget reallocations in other domains.

The main results of this paper are the following. The funding reform had a significant and positive impact on expenditures in education for its net recipients. An $\mathrm{R} \$ 1.00$ per capita increase in FUNDEF per capita is associated with a $\mathrm{R} \$ 0.57$ per capita increase in education expenditures. For those municipalities that received resources from the fund there was a significant increase in the mayor's chances of reelection. For a municipality to which FUNDEF net transfers were the double it contributed to the fund there was a correpondent 6.1 percentage points increase in the incumbent mayors chances of reelection.

This electoral impact may have been caused by improvements in the quality of schools. There is some evidence that FUNDEF impacted school quality, which could be a possible channel for the increase on mayors chances of reelection. FUNDEF significantly increased teachers education level and school infrastructure.

The paper is organized as follows. Section 2 discusses the relevant literature an related works. Section 3 presents FUNDEF institutional framework. Data sources are described in section 4 and the identification strategy is detailed in section 5 . The results are presented in section 6 and section 7 concludes. 


\section{Related Literature}

This work studies the electoral impact of education expenditures and disentangles it from policy setting and the so-called political budget cycles. Initially, it relates to the initial literature of empirical studies on voting behavior. Works such as Kramer (1971) and Mueller (1970) began the practice of assessing voter behavior using econometric tools.

As stated in section 1, the relationship between the policy decisions of politicians and the voting decisions of voters runs through two channels. The pre-electoral politics, where politicians decide policy based on their beliefs and information about voters preferences and the post-electoral politics, where voters decide whether to vote or not for a politician based on their beliefs and the information about her, including the previous implemented policy.

Extensive literature of the political budget cycles (Rogoff, 1990) studies the first channel, namely the variation of public expenses according to the election cycle. Those studies assess the change in public spending in campaign periods (ALESINA; PEROTTI, 1995; BRENDER; DRAZEN, 2005; NAKAGUMA, 2006). Others, like this one, study the second channel and the response of voters to the implemented policy.

As regards voters and post-electoral politics, Peltzman (1992), in a seminal reference in the field, finds evidence from American elections from 1950 to 1988 that voters punish presidential candidates and state governments that carry higher expenses. The results are even more significant if these expenses are realized during election periods.

Analysing Israel municipal elections of 1989, 1993 and 1998, Brender (2003) also notes a tax effect on the chances of reelection of local governors. The result, however, only appears in the 1998 elections, after institutional reforms. The reforms imposed hard budget constraints and increased rigor in audits of local governments expenditures by the central government, which suggests that voters behavior may change over time and depend on specific institutional features.

In a cross-country analysis, Brender and Drazen (2008) do not find evidence that a 
politician will benefit from increases in public deficits in national elections. Nevertheless, they find different results for developed and developing countries. For groups of developed countries and established democracies, the evidence indicates that voters punish candidates that increase government spending in election periods, results similar to the ones of Peltzman (1992) for the US. For developing countries, however, they find political rewards of higher spending. This corroborates the evidence of the same authors that the electoral political cycles (political deficit cycles) observed by other authors in a panel of countries are driven by the effects on "new democracies" (BRENDER; DRAZEN, 2005).

With regard to municipal elections in Brazil, Meneguin, Bugarin and Carvalho (2005) find evidence that the voters tend to punish governments with expansionary fiscal policies, this way approaching Brazilian voters to the American according Peltzman (1992). Those authors also discuss the simultaneity of the political action and the response of voters with regard to public expenditure, since politicians can change the expenditure profile according to their perception of the reelection chances or the electorate trend.

Following the same literature, Sakurai and Menezes Filho (2007) use a logit model and include political variables (such as political alignment to the governor and the president) to assess electoral political cycles in Brazilian municipalities. The authors found similar results to Peltzman (1992) and Brender and Drazen (2008), indicating that voters punish deficits in election years. In non-election years, however, the expenditures are positively assessed. In addition, they show that the political alignment of the mayor and the federal transfers received positively influence the chances of reelection.

The above articles, however, make no specific analysis for education. This study focus specifically on education with respect to political accountability on the part of voters. More specifically, this paper aims to identify the response of voters to a change in spending on education. Voters perceive increased spending on education? How does this affect their voting choices?

Regarding political budget cycles and pre-electoral politics, few articles evaluate the educational expenditure choices of incumbents in election years. Decomposing public 
spending of municipalities between 1990 and 2005 in different budgetary functions, Sakurai (2009) finds no significant variation in spending on education and culture in election years. These results indicate the existence of more pronounced electoral cycles for health functions and sanitation, housing and urban planning, assistance and welfare and transport.

Regarding voting behavior, Mendes and Rocha (2004) seek to break down the chances of reelection of a mayor in Brazil on several factors such as corruption charges, public health, fiscal responsability and education. With respect to latter, the authors include the level of education of teachers of 5 th to 8th grade and the variation in the number of teachers of 1st to 4th grade, but find no impact on the the incumbent mayor's reelection probability.

In an article closely related to this work, Firpo, Pieri and Souza (2012) assess the electoral impact of improved quality in education. The authors use information on the results of the Basic Education Development Index (IDEB) of 2005 and 2007 and electoral data of 2004 and 2008 to evaluate how the publication of results of a school quality index affected the relationship between improvements in school quality and the chance of reelection of mayors.

The authors find evidence that changes in IDEB, on average, positively affect the chances of reelection of a mayor. The increase of one unit in IDEB from 2005 to 2007 increases the chances of reelection of a mayor in 5 percentage points. The increase was greatest for the poorest cities and the ones where there are more children, reaching 10 percentage points.

In his masters dissertation, Janke (2013) assesses whether the expenditure of municipalities on kindergarten, primary and low secondary education, including transfers of federal funds (FUNDEF and FUNDEB - its successor) have electoral impact. The author also seeks to identify in which year of the mandate spending has a greater impact on the chance of reelection. He finds evidence that spending on education by local governments contributes to the mayor's and party's reelection (JANKE, 2013, p.38). The effects are more significant for early childhood education. 
This work differs from Janke (2013), first by using the net revenue introduced by FUNDEF, while he uses the gross revenue from the funds, i.e. he does not account for the municipalities contributions for the fund. It is an important distinction once those contributions largely alter the fund's impact on municipalities' education budget. In addition, the analysis proposed will make a division between municipalities that gained and the ones that lost resources to the fund to be detailed ahead. The effects of FUNDEF on education expenditures are different for the groups, making the aggregate effect elusive.

Moreover, important additional contributions of the work here presented in relation to Janke (2013) are to explain the relation between the fund transfers and education expenditures and to disentangle the simultaneous channels aforementioned. We estimate the funds impact on educational spending and disentangle the effects of the voters response from the possible endogenous actions of the politicians. 


\section{Institutional Background}

The 1988 Brazilian Constitution states that education is compulsory from 4 to 17 years and that the government is responsible for its provision and must offer it free of charge. The Constitution also states that all federal entities (states and municipalities) should spend at least $25 \%$ of their revenues in public education.

States and municipalities have their own school systems, so that the public schools are either state or municipal schools. States are in charge of primary and low secondary levels and municipalities are in charge of primary level. Primary and low secondary education in Brazil were almost universalized by the 1990s. Among the kids in those levels, around 90\% studied in public schools in 1997 (ESTEVAN, 2014).

The quality, nevertheless, had major shortcomings . The challenge of improving the educational level of the country ran up against, among other problems, the great heterogeneity of resources between the states, and within each state, between the municipalities.

The resources constitutionally destined to education were linked to federal entities' revenues. Hence, education budgets presented great inequality across states and municipalities. To address such an issue the federal government passed an education finance reform in 1998. The reform was called Fund for Maintenance and Development of Fundamental Education and Valuing of Teacher (FUNDEF).

FUNDEF had the objective of redistributing resources for education. $15 \%$ of the states and municipalities revenues from the main taxes and transfers were sent to a fund created within each state. The resources were then redistributed to that state and its municipalities according to the share of students enrolled in each of their school systems.

Each municipality still had to spend $25 \%$ of their income on education . With FUNDEF, however, $15 \%$ (60\% of the $25 \%$ ) of the revenues should be sent to the Fund. The remaining $10 \%$ (40\% of $25 \%$ ) were still to be spent on education in its own federal entity.

More specifically, FUNDEF was established within each state and the Federal 
District and consists of $15 \%$ of both the state and municipalities revenues from:

1. state value-added tax - ICMS, due to the Federal District, the states and the municipality;

2. participation fund of the States and the Federal District - FPE and municipalities FPM;

3. federal value-added tax - IPI due to the states and the Federal District; and

4. the amount of funds transferred in cash by the Union to the States, Federal District and municipalities as financial compensation for loss of income resulting from the exemption of exports, according to Supplementary Law No. 87 of September 13, 1996.

In detail, municipalities' contributions to the fund pool in their state are calculated according the equation below:

$$
\text { Contribution }_{i t}=0.15 *\left(F P M_{i t}+I C M S_{i t}+I P I_{i t}+L C 87 / 96_{i t}\right)
$$

Where: $F P M_{i}, I C M S_{i}$ and $I P I_{i t}$ are the total FPE, ICMS and IPI received by municipality $i$ at year $t$ and $L C 87 / 96_{i t}$ is the total amount received by the municipality $i$ on year $t$ according to the Complementary Law nº $87 / 96$.

Then, the net transfers from FUNDEF are calculated deducting their contributions on year $t$ from the amount they received on the same year.

For some municipalities, the calculated values for the net fund transfers are too extreme. As a measure of caution, observations with values more than 4 standard deviations from the mean were dropped (it represented less than $1 \%$ of the data). Municipalities with no public school at the year of 1998 are also excluded from the anlysis.

Moreover, it was added a complement of the Union when, within each state and the Federal District, the amount per student did not reach a nationally set minimum. 
It is important to mention that none of those sources is subject to municipal choice. As it was mentioned above, the fund is formed using resources of federal and state tax and transfers.

Formed the total pool of resources within each state and the Federal District, resources were then distributed to the state and municipalities in proportion to the number of students enrolled annually in schools registered their respective school systems, considering enrollment from 1st to 8 th elementary school grades. Those resources must have been used exclusively on the maintenance and development of the public elementary education, particularly on teachers, so that:

- A minimum of $60 \%$ annually for the remuneration of teaching professionals in effective exercise in public elementary school, including teachers and professionals working in educational support activities;

- The remaining funds (up to $40 \%$ of the total) is directed to various expenses considered as "maintenance and development of education".

Those expenditures were audited by specific local committees formed within each municipality on a monthly basis. They were also audited by the accounting court on a annual basis.

The redistributive role of the fund, the resource allocation rules and supervision suggest that we should expect quality improvements as a result of FUNDEF.

FUNDEF provided resources for the education budget. We can then, in principle, use the fund as a source of exogenous variation in education spending and assess the impact of those expenditures on the choice of the voters. To disentangle the two aforementioned channels, however, we need the fund to be independent of the choice and control of mayors. FUNDEF had three main components: the rule, the revenues and the enrollment data.

The rule was defined at the national level and imposed on states and municipalities. Regarding the possibility of mayors manipulation of the FUNDEF rule definition it is important to emphasize that the law was defined by national congress and mayors have 
no direct representation on it. Brazil has more than 5000 municipalities and a mayor has too little power to influence decisions at the national level.

Some of the revenues of a municipality might be subject to mayors' choices, but the ones used to finance the fund resources are not. FPM, ICMS, IPI and the compensation from the law 87/96 are all defined at higher spheres of government.

There is still room for possible endogeneity on the other sources of revenue and enrollment. There is some evidence that FUNDEF, as will be presented in section 6, is related also to transport expenditures in a lesser amount than education expenditures. It is not possible, notwithstanding to interpret this paper's results solely as due to education, those second order effects must be taken into account.

Additionally, regarding enrollment, we use hypothetical fund transfers that exclude the possibility of manipulation. We make use of the timing of the implementation of FUNDEF to use the simulated transfers as an instrument to the actual transfers as it is going to be explained in the Empirical Strategy section. 


\section{Data}

This paper uses data from different sources. First, it uses data on the 1996 and 2000 Brazilian municipal elections. Second, it uses tax information from municipalities and the federal government. Finally, it uses socioeconomic and educational indicators at the municipal level.

The electoral data was obtained in the electoral data repository of the Superior Electoral Court (TSE, Tribunal Superior Eleitoral, 2015) . The court provides information about candidates in the race and their votes and party affiliation. The data is avaliable at the precinct level.

Most of municipalities are comprised of one precint, while the biggest ones have more than one precint.For this study the data was aggregated at municipal level. We have data on candidates and winners of 1996 and 2000 elections and their respective parties. The candidates of 2000 election were compared to 1996 winners and incumbents were identified. We also have data on incumbents' parties and the parties of the governor of the state and the President of the Republic.

Other key data used are amounts provided and received from FUNDEF to states and municipalities. The data regarding the transfer of the fund to the federal entities are obtained on the website of constitutional transfers of National Treasury (TESOURO, Tesouro Nacional, 2015).

The contribution of the municipalities for the fund, however, must be calculated according to the rule of the fund from tax information of the municipalities obtained using National Treasury's FINBRA (Finance of Brazil) database and State Departments of Finance and the above mentioned data from the National Treasury.

The data regarding municipalities' finance is used to obtain the $15 \%$ transferred to the fund, as explained above. This amount is then deducted from the total received by the municipality to obtain the net transfers from the fund to the municipality's education budget. 
The data on school quality is obtained from the School Census of the years from 1996 to 2000. It has data on class sizes, teachers education and number of schools with libraries, laboratories, sports facilities and water and energy provision. For the year of 1997 there is no data on teachers education, so the data from 1996 is used instead.

In addition to the above data, others variables are used as controls, such as age composition of the population, economic indicators and public budget information from municipalities. Those are collected in IPEADATA, the IBGE and FINBRA database.

The main variables used are:

Education $=$ the municipal education expenditure per capita;

Total revenue ${ }^{1}$ - the municipal tax and transfer revenue per capita;

Tax revenue - the municipal tax revenue per capita;

State transfers - the municipal state transfers revenue per capita;

Federal transfers - the municipal federal transfer revenue per capita;

FUNDEF - the net municipal revenue per capita from the fund per capita;

FUNDEF 1997 - the net municipal revenue per capita from the simulated fund per capita;

FUNDEF impact - the average impact variable described above;

FUNDEF impact $199^{\prime \prime}$ - the average impact variable described calculated for the simulated FUNDEF;

Elected is a dummy that takes the value of 0 in case of a mayor having lost the 2000 election and the value of 1 in case he won it;

Governor party - Dummy variable which takes value 1 if the mayor's party is the same as the governor's one and 0, otherwise;

President party - Dummy variable which takes value 1 if the mayor's party is the

$\overline{1}$ None of the revenue variables includes FUNDEF revenues 
same as the President's one and 0, otherwise;

Population - Total population in 2000;

Elderly population - Proportion of old (here considered as people above 60 years old) people in the population;

Young population - Proportion of young (here considered as people between 5 and 19 years old) people in the population;

Urban - Urban population as a share of total population.

Class Size - Mean class size of municipal schools in a given municipality.

Primary - Mean proportion of teachers with primary education (complete or incomplete).

Secondary - Mean proportion of teachers with secondary education (complete or incomplete).

Tertiary - Mean proportion of teachers with tertiary education (complete or incomplete).

Water - Proportion of schools with water supply in the municipality.

Energy - Proportion of schools with energy supply in the municipality.

Sports facility - Proportion of schools with a sports facility in the municipality.

Library - Proportion of schools with a library in the municipality.

Science Laboratory - Proportion of schools with a science laboratory in the municipality.

Table 1 below presents summary statistics of the main variables: 
Table 1 - Summary statistics

\begin{tabular}{|c|c|c|c|}
\hline VARIABLES & $\begin{array}{c}(1) \\
\text { Mean } \\
\end{array}$ & $\begin{array}{c}(2) \\
\text { Std. Dev. }\end{array}$ & $\begin{array}{l}(3) \\
\mathrm{N}\end{array}$ \\
\hline Education & 162.472 & 256.884 & 3,435 \\
\hline Total revenue & 340.910 & 668.837 & 3,435 \\
\hline Tax revenue & 20.291 & 57.439 & 3,435 \\
\hline State transfers & 110.488 & 142.820 & 3,435 \\
\hline Federal transfers & 209.048 & 579.450 & 3,435 \\
\hline FUNDEF & 0.313 & 38.558 & 3,435 \\
\hline FUNDEF 1997 & -6.183 & 32.316 & 3,021 \\
\hline FUNDEF impact & 0.326 & 0.977 & 3,435 \\
\hline FUNDEF impact 1997 & 0.160 & 1.121 & 3,021 \\
\hline Elected & 0.519 & 0.500 & 3,435 \\
\hline Young population & 0.403 & 0.0448 & 3,435 \\
\hline Elderly population & 0.098 & 0.025 & 3,435 \\
\hline Urban & 0.609 & 0.234 & 3,435 \\
\hline Population & $34,947.900$ & $225,406.200$ & 3,435 \\
\hline Governor party & 0.251 & 0.434 & 3,435 \\
\hline President party & 0.184 & 0.388 & 3,435 \\
\hline Transfers & 29.648 & 58.401 & 3,435 \\
\hline Other state transfers & 10.193 & 14.943 & 3,435 \\
\hline Other federal transfers & 19.455 & 55.904 & 3,435 \\
\hline Housing & 47.141 & 104.311 & 3,435 \\
\hline Health and sanitation & 82.080 & 83.053 & 3,435 \\
\hline Social security & 34.663 & 141.687 & 3,435 \\
\hline Transport & 36.588 & 60.241 & 3,435 \\
\hline Agriculture & 12.037 & 20.879 & 3,435 \\
\hline Industry trade and services & 3.461 & 11.957 & 3,435 \\
\hline Energy and mineral resources & 1.244 & 3.999 & 3,435 \\
\hline Communications & 1.110 & 3.981 & 3,435 \\
\hline Defense and security & 0.953 & 4.458 & 3,435 \\
\hline Regional development & 0.470 & 3.443 & 3,435 \\
\hline Other functions & 2.407 & 15.29 & 3,435 \\
\hline Library & 0.189 & 0.257 & 3,276 \\
\hline Science Laboratory & 0.0447 & 0.123 & 3,276 \\
\hline Sports facility & 0.173 & 0.251 & 3,276 \\
\hline Water & 0.946 & 0.122 & 3,276 \\
\hline Energy & 0.727 & 0.306 & 3,276 \\
\hline Class Size & 23.200 & 5.953 & 3,276 \\
\hline Primary & 0.134 & 0.179 & 3,284 \\
\hline Secondary & 0.650 & 0.194 & 3,284 \\
\hline Tertiary & 0.216 & 0.217 & 3,284 \\
\hline
\end{tabular}

The mean education expenditures per capita in data were $\mathrm{R} \$ 162.472$ with a standard deviation of $\mathrm{R} \$ 256.884$. This relates to total revenues per capita of $\mathrm{R} \$ 340.909$ with standard deviation of $\mathrm{R} \$ 668.837$. Mean FUNDEF net transfers per capita were $\mathrm{R} \$ 0.313$ with a standard deviation of $\mathrm{R} \$ 38.558$. Those transfers produced a mean FUNDEF impact of 0.326 with a 0.977 standard deviation. 
This work studies the impact of education expenditures in the reelection chances of incumbent mayors. Therefore, only municipalities where the incumbent mayor ran for reelection are used in the main estimations. Table 2 below presents descriptive statistics for those municipalities and the remaining ones, where the mayor did not run for reelection.

Table 2 - Summary statistics by incumbent mayor running or not for reelection

\begin{tabular}{|c|c|c|c|c|c|c|}
\hline \multirow[b]{3}{*}{ VARIABLES } & \multirow{3}{*}{$\begin{array}{c}(1) \\
\text { Incumbent not running } \\
\text { Mean }\end{array}$} & \multirow[t]{2}{*}{$(2)$} & \multirow[t]{2}{*}{ (3) } & \multirow{2}{*}{$\begin{array}{c}\text { (4) } \\
\text { Incumbent running }\end{array}$} & \multirow[t]{2}{*}{$(5)$} & \multirow[t]{2}{*}{ (6) } \\
\hline & & & & & & \\
\hline & & Std. Dev. & $\mathrm{N}$ & Mean & Std. Dev. & $\mathrm{N}$ \\
\hline Education & 157.833 & 81.542 & 1,257 & 165.149 & 316.601 & 2,178 \\
\hline Total revenue & 341.800 & 207.524 & 1,257 & 340.4396 & 825.101 & 2,178 \\
\hline Tax revenue & 17.017 & 25.372 & 1,257 & 22.180 & 69.448 & 2,178 \\
\hline State transfers & 115.278 & 108.501 & 1,257 & 107.724 & 159.256 & 2,178 \\
\hline Federal transfers & 208.316 & 144.265 & 1,257 & 209.471 & 719.461 & 2,178 \\
\hline FUNDEF & -6.228 & 38.489 & 1,257 & 4.088 & 38.099 & 2,178 \\
\hline FUNDEF 1997 & -11.314 & 33.353 & 1,151 & -3.026 & 31.255 & 1,870 \\
\hline FUNDEF impact & 0.152 & 0.885 & 1,257 & 0.426 & 1.013 & 2,178 \\
\hline FUNDEF impact 1997 & 0.001 & 0.997 & 1,151 & 0.259 & 1.181 & 1,870 \\
\hline Elected & 0.458 & 0.498 & 1,257 & 0.554 & 0.497 & 2,178 \\
\hline Young population & 0.396 & 0.044 & 1,257 & 0.407 & 0.045 & 2,178 \\
\hline Elderly population & 0.101 & 0.025 & 1,257 & 0.097 & 0.024 & 2,178 \\
\hline Urban & 0.616 & 0.227 & 1,257 & 0.606 & 0.238 & 2,178 \\
\hline Population & $34,623.020$ & $302,254.600$ & 1,257 & $35,134.830$ & $165,640.000$ & 2,178 \\
\hline Governor party & 0.212 & 0.409 & 1,257 & 0.274 & 0.446 & 2,178 \\
\hline President party & 0.146 & 0.354 & 1,257 & 0.206 & 0.404 & 2,178 \\
\hline Transfers & 28.475 & 23.767 & 1,257 & 30.325 & 71.083 & 2,178 \\
\hline State transfers & 10.993 & 13.331 & 1,257 & 9.731 & 15.784 & 2,178 \\
\hline Federal transfers & 17.482 & 18.16 & 1,257 & 20.594 & 68.819 & 2,178 \\
\hline Housing & 43.811 & 35.472 & 1,257 & 49.064 & 128.167 & 2,178 \\
\hline Health and sanitation & 82.079 & 50.207 & 1,257 & 82.080 & 97.089 & 2,178 \\
\hline Social security & 32.450 & 27.327 & 1,257 & 35.941 & 176.724 & 2,178 \\
\hline Transport & 38.145 & 41.826 & 1,257 & 35.689 & 68.650 & 2,178 \\
\hline Agriculture & 12.831 & 18.304 & 1,257 & 11.580 & 22.221 & 2,178 \\
\hline Industry trade and services & 3.427 & 9.127 & 1,257 & 3.480 & 13.321 & 2,178 \\
\hline Energy and mineral resources & 1.219 & 3.963 & 1,257 & 1.259 & 4.020 & 2,178 \\
\hline Communications & 1.131 & 3.075 & 1,257 & 1.098 & 4.421 & 2,178 \\
\hline Defence and security & 0.950 & 4.128 & 1,257 & 0.955 & 4.638 & 2,178 \\
\hline Regional development & 0.389 & 2.878 & 1,257 & 0.518 & 3.730 & 2,178 \\
\hline Other functions & 3.031 & 18.247 & 1,257 & 2.047 & 13.282 & 2,178 \\
\hline Library & 0.206 & 0.272 & 1,180 & 0.180 & 0.248 & 2,096 \\
\hline Science Laboratory & 0.049 & 0.132 & 1,180 & 0.042 & 0.117 & 2,096 \\
\hline Sports facility & 0.185 & 0.256 & 1,180 & 0.166 & 0.248 & 2,096 \\
\hline Water & 0.953 & 0.114 & 1,180 & 0.942 & 0.127 & 2,096 \\
\hline Energy & 0.734 & 0.305 & 1,180 & 0.724 & 0.306 & 2,096 \\
\hline Class Size & 22.226 & 6.062 & 1,180 & 23.748 & 5.821 & 2,096 \\
\hline Primary & 0.124 & 0.172 & 1,183 & 0.140 & 0.183 & 2,101 \\
\hline Secondary & 0.645 & 0.196 & 1,183 & 0.652 & 0.193 & 2,101 \\
\hline Tertiary & 0.231 & 0.225 & 1,183 & 0.208 & 0.211 & 2,101 \\
\hline
\end{tabular}

Once we divide the data in municipalities whose mayor ran or not for reelection we see that for municipalities with a running incumbent mayor the mean education expenditure per capita was $\mathrm{R} \$ 165,149$ with a standard deviation of $\mathrm{R} \$ 316.601$, for the ones where the incumbent did not run it was $\mathrm{R} \$ 157.833$ with a standard deviaton of $\mathrm{R} \$ 81.542$. The mean total revenues on the former were $\mathrm{R} \$ 340.396$ and on the latter, $\mathrm{R} \$ 341.800$. 
Mean FUNDEF net transfers on municipalities with a running mayor were $\mathrm{R} \$ 4.088$ with a standard deviation of $\mathrm{R} \$ 38.099$. They generated a mean FUNDEF impact of 0.426 with a standard deviation of 1.013 For the remaining municipalities the mean net FUNDEF transfers were negative $\mathrm{R} \$ 6.227$ with a standard deviation of $\mathrm{R} \$ 38.489$. Those generated a mean FUNDEF impact of 0.152 with a standard deviation of 0.885 . 


\section{Empirical Strategy}

The question this work aims to answer is: what is the impact of education expenditures in the reelection chances of a mayor? Ideally, to estimate the effect of education spending in a given municipality, we would compare a given municipality in a given moment of time, in an election with the same candidates and different levels of spending. But this is clearly not possible. We must then compare a given municipality in different elections or different municipalities in a given election and changes in public spending on education between municipalities or over time.

An issue here is the potential endogeneity of education and other expenditures. It is reasonable to assume that the variation of education expenditure across municipalities is influenced not only on grounds of public policy, but also by the expectations of the mayor regarding the possibility of reelection. In other words, the first and second channels aforementioned are entangled.

One way to disentangle the two channels and identify the impact of spending on education in the probability of reelection, is to use expenditures exogenous to the choice of the municipal administration, such as federal transfers as FUNDEF.

As explained in the Institutional Background section, FUNDEF transfers are calculated following a rule defined by a federal law. The transfers must be spent entirely on education and are not subject to mayor's discretion. It is expected that the fund affects educational spending and not other expenditures.

I use the same variable impact used by Estevan (2014) to evaluate the effect of the introduction of constitutional transfers of the fund in the education budget of the municipalities. The variable is calculated as follows :

$$
\text { FUNDEFimpact }_{i}=\frac{I_{i}-O_{i}}{O_{i}}
$$

Where $O_{i}$ is the total sent to the fund by the municipality $i$ and $I_{i}$ is the total 
received by the municipality $i$.

The use of the impact variable as the main explanatory variable aims to: $(i)$ provide a relative measure of this variation, allowing equate municipalities with populations and budgets of different magnitudes and $(i)$ capture the shock caused by the introduction of funds in the budget of the municipalities.

A reasonable concern about using FUNDEF relates to the possibility of an omitted variable influencing both the election results and the FUNDEF transfers. An skilled mayor, for instance, could take more children to the school and improve health services, which would have an impact in his reelection chances and the transfer received from FUNDEF.

To address such concern, we calculate a simulated FUNDEF variable using enrollment and tax and transfer data from 1997 following Kosec (2011). Since the financial and enrollment data were collected before the FUNDEF rules were defined this variable is not affected by mayor's possible manipulation of school enrollment or municipal taxes collection. The variable is calculated as described in equation (5.1) below.

$$
\text { FUNDEF_1997 } i=F U N D E F \_r e v e n u e \_1997_{i}-\text { Contribution_1997 } 7_{i}
$$

Where: Contribution_1997 ${ }_{i}=0.15 *\left(F P M \_1997_{i}+\right.$ ICMS_1997 $i+I P I \_1997_{i}+$ $\left.L C 87 / 96_{1} 1_{1997_{i}}\right)$ is the hypothetical contribution municipality $i$ would have made to the fund with financial data from 1997.

FUNDEF_revenue_1997 is the amount that would have been received from the fund if all contributions were the ones above and enrollment data had the values of 1997 .

FUNDEF was first mentioned in constitutional amendment number 14 which was enacted on september 12th 1996. The fund rules were defined by decree number 2.264 on June 27th, 1997, after the enrollment data had been collected that year ${ }^{1}$. The variable thus created is exogenous to the mayors' anticipation and can be used as an instrument for the subsequent actual FUNDEF.

1 The enrollment data is collected between March and April each year. 


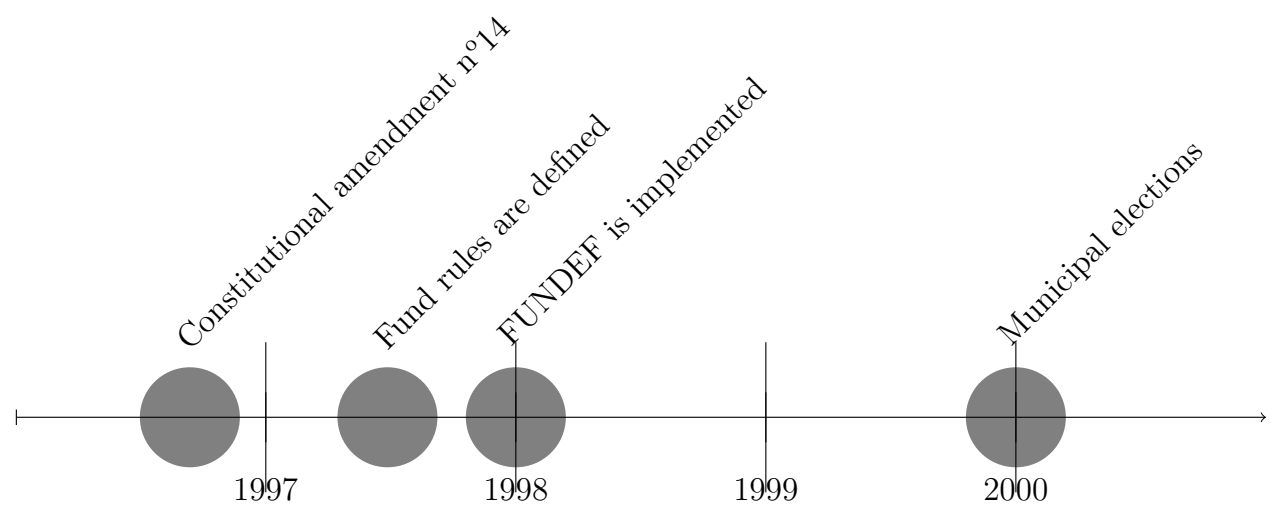

To use the simulated FUNDEF as an instrument it is important that it is correlated with the actual FUNDEF, given the controls we are going to use. To test this we estimate simulated FUNDEF impact on actual FUNDEF, the first stage of the regressions using the instrument. In other words we estimate:

$$
\text { FS : FUNDEF } F_{i}=\alpha+\beta_{1} X_{i}+\beta_{2} F U N D E F 97_{i}+\epsilon_{i}
$$

The results are showed in Table 3 below.

As expected, simulated FUNDEF is strongly correlated with actual FUNDEF net transfers. FUNDEF_97 coefficient is 0.89 and significant at the $1 \%$ level and it decreases to 0.85 , mantaining its significance once we add demographic (column 2) and political (column 3) controls.

The simulated FUNDEF is positively correlated with Tax revenue which has a coefficient of approximately 0.35 and negatively correlated with State transfers and Federal transfers with coefficients of -0.05 and -0.11 respectively. F-statistics is high, over 500, removing the risk of a weak instrument. 
Table 3 - FUNDEF instrumented by simulated FUNDEF97: First stage

\begin{tabular}{|c|c|c|c|}
\hline VARIABLES & $\begin{array}{c}(1) \\
\text { All municipalities }\end{array}$ & $\begin{array}{c}(2) \\
\text { All municipalities }\end{array}$ & $\begin{array}{c}(3) \\
\text { All municipalities }\end{array}$ \\
\hline Tax revenue & $\begin{array}{c}0.033^{* * *} \\
(0.012)\end{array}$ & $\begin{array}{c}0.035^{* * *} \\
(0.012)\end{array}$ & $\begin{array}{c}0.035^{* * *} \\
(0.012)\end{array}$ \\
\hline State transfers & $\begin{array}{c}-0.050^{* * *} \\
(0.015)\end{array}$ & $\begin{array}{c}-0.049^{* * *} \\
(0.016)\end{array}$ & $\begin{array}{c}-0.050^{* * *} \\
(0.016)\end{array}$ \\
\hline Federal tranfers & $\begin{array}{c}-0.011^{* * *} \\
(0.003)\end{array}$ & $\begin{array}{c}-0.011^{* * *} \\
(0.003)\end{array}$ & $\begin{array}{c}-0.011^{* * *} \\
(0.003)\end{array}$ \\
\hline FUNDEF 97 & $\begin{array}{c}0.886^{* * *} \\
(0.030)\end{array}$ & $\begin{array}{c}0.850^{* * *} \\
(0.032)\end{array}$ & $\begin{array}{c}0.850^{* * *} \\
(0.032)\end{array}$ \\
\hline Young population & & $\begin{array}{c}64.831^{* * *} \\
(19.470)\end{array}$ & $\begin{array}{c}61.727^{* * *} \\
(19.622)\end{array}$ \\
\hline Elderly population & & $\begin{array}{c}6.741 \\
(25.036)\end{array}$ & $\begin{array}{c}2.961 \\
(25.414)\end{array}$ \\
\hline Urban & & $\begin{array}{c}4.557^{* * *} \\
(1.547)\end{array}$ & $\begin{array}{l}4.014^{* *} \\
(1.557)\end{array}$ \\
\hline Governor_party & & & $\begin{array}{l}1.382^{*} \\
(0.743)\end{array}$ \\
\hline President_party & & & $\begin{array}{c}1.020 \\
(0.719)\end{array}$ \\
\hline Constant & $\begin{array}{c}10.905^{* * *} \\
(1.423)\end{array}$ & $\begin{array}{c}-18.791^{*} \\
(11.16)\end{array}$ & $\begin{array}{l}-17.426 \\
(11.25)\end{array}$ \\
\hline Observations & 1,870 & 1,870 & 1,870 \\
\hline R-squared & 0.863 & 0.867 & 0.868 \\
\hline Demographic controls & No & No & No \\
\hline Political controls & No & No & No \\
\hline
\end{tabular}

Note $-{ }^{*}$ significant at $10 \%,{ }^{* *}$ significant at $5 \% * * *$ significant at $1 \%$. Robust standard errors are in parentheses. 


\section{FUNDEF's impact on municipal expenditures}

To analyze the impact of education expenditures on reelection chances it is important that FUNDEF actually impact education. It is also important that FUNDEF, our exogenous measure of education spending is uncorrelated with other variables that could affect political outcomes. If FUNDEF affects other expenditures, for instante, it is possible that the results on voting are driven by this channel.

This section measures how FUNDEF impacts education expenditures and evaluates wheter it impacts other variables that could in principle affect reelection chances.

\subsubsection{FUNDEF effects on education expenditures}

To assess the effect of FUNDEF transfers on municipal education expenditures we do the following two-stages estimation:

$$
\text { FS : FUNDEF } F_{i}=\alpha+\beta_{1} X_{i}+\beta_{2} F U N D E F 97_{i}+\epsilon_{i}
$$

$$
\text { SS : } E d u c_{i}=\alpha+\beta_{1} X_{i}+\beta_{2} F U \hat{N D E F_{i}}+\epsilon_{i}
$$

Firsts stage results were shown in Table 3 above. The second stage results are showed in Table 4 below. As expected, education expenditures are strongly correlated with tax and transfer revenues. For all municipalities the coefficients on Tax revenues, State tranfers are 0.261 and 0.562 respectively and significant at the $5 \%$ level. Federal transfers coefficient is 0.364 and significant at the $1 \%$ level as can be seen in column (1).

The relation between education expenditures and the fund revenues is also positive. FUNDEF coefficient is 0.704 , as shows column (1). It is not, however, significant as it would be expected.

This result, however, averages the impact for municipalities that gained and municipalities that lost resources with the funding reform. Those, that have a negative 
net revenue from the fund will from now on be called "net contributors". The others, that have a positive net revenue, will be called "net recipients".

Table 4 - 2SLS estimates of FUNDEF's impact on education expenditure 1998-2000

\begin{tabular}{|c|c|c|c|c|c|c|}
\hline VARIABLES & $\begin{array}{c}\text { (1) } \\
\text { All municipalities }\end{array}$ & $\begin{array}{l}(2) \\
\text { Net recipients }\end{array}$ & $\begin{array}{c}(3) \\
\text { Net contributors }\end{array}$ & $\begin{array}{c}(4) \\
\text { All municipalities }\end{array}$ & $\begin{array}{l}5) \\
\text { Net recipients }\end{array}$ & $\begin{array}{c}(6) \\
\text { Net contributors }\end{array}$ \\
\hline Tax revenue & $\begin{array}{c}0.261^{* *} \\
(0.130)\end{array}$ & $\begin{array}{c}0.319^{* * *} \\
(0.0201)\end{array}$ & $\begin{array}{c}0.165 \\
(0.319)\end{array}$ & $\begin{array}{c}0.315^{* * *} \\
(0.100)\end{array}$ & $\begin{array}{c}0.329^{* * *} \\
(0.0234)\end{array}$ & $\begin{array}{c}0.306 \\
(0.192)\end{array}$ \\
\hline State transfers & $\begin{array}{c}0.562^{* *} \\
(0.263)\end{array}$ & $\begin{array}{l}0.498^{* * *} \\
(0.0278)\end{array}$ & $\begin{array}{c}0.614 \\
(0.418)\end{array}$ & $\begin{array}{c}0.590^{* *} \\
(0.284)\end{array}$ & $\begin{array}{l}0.538^{* * *} \\
(0.0367)\end{array}$ & $\begin{array}{c}0.686 \\
(0.480)\end{array}$ \\
\hline Federal transfers & $\begin{array}{l}0.364^{* * * *} \\
(0.0119)\end{array}$ & $\begin{array}{l}0.485^{* * *} \\
(0.0213)\end{array}$ & $\begin{array}{l}0.367^{* * * *} \\
(0.0155)\end{array}$ & $\begin{array}{l}0.358^{* * *} \\
(0.0122)\end{array}$ & $\begin{array}{l}0.474^{* * *} \\
(0.0269)\end{array}$ & $\begin{array}{c}0.359^{* * *} \\
(0.0128)\end{array}$ \\
\hline FUNDEF & $\begin{array}{c}0.704 \\
(0.577)\end{array}$ & $\begin{array}{l}0.642^{* * *} \\
(0.0781)\end{array}$ & $\begin{array}{l}1.153 \\
(1.735)\end{array}$ & $\begin{array}{c}0.655 \\
(0.557)\end{array}$ & $\begin{array}{l}0.573^{* * *} \\
(0.0806)\end{array}$ & $\begin{array}{l}1.356 \\
(1.910)\end{array}$ \\
\hline Constant & $\begin{array}{c}19.59 \\
(26.75)\end{array}$ & $\begin{array}{c}4.201 \\
(4.371)\end{array}$ & $\begin{array}{c}27.55^{* *} \\
(13.80)\end{array}$ & $\begin{array}{l}-125.1 \\
(131.3)\end{array}$ & $\begin{array}{c}-63.79^{* *} \\
(32.04)\end{array}$ & $\begin{array}{l}-329.9 \\
(313.4)\end{array}$ \\
\hline Observations & 1,870 & 973 & 897 & 1,870 & 973 & 897 \\
\hline R-squared & 0.930 & 0.746 & 0.933 & 0.931 & 0.748 & 0.935 \\
\hline Demographic controls & No & No & No & Yes & Yes & Yes \\
\hline Political controls & No & No & No & Yes & Yes & Yes \\
\hline
\end{tabular}

Note $-{ }^{*}$ significant at $10 \%,{ }^{* *}$ significant at $5 \% * * *$ significant at $1 \%$. Robust standard errors are in parentheses. Demographic controls are urban, elderly proportion, and young proportion. Political controls are president party and governor party.

Once we divide the sample in net recipients and net contributors of FUNDEF it is clear that the effects of FUNDEF are not the same for all municipalities. For net contributors FUNDEF's impact on education expenditures has no significant effect (column $3)$.

For net recipients though, FUNDEF positively affects educational expenditures (column 2). The coefficient of FUNDEF is 0.642 and significant at the $1 \%$ level for this sub-sample.

Adding political and demographic controls to the above estimation increases Tax revenue and State transfers coefficients to 0.315 and 0.590 and reduces Federal transfers one to 0.358. Nevertheless FUNDEF's impact on the education expenditures for all municipalities presents now a bigger coefficient it is still not significant (column 4).

The results for the divided sample, notwithstanding, present little change. While the FUNDEF coefficient for net contributors remains small and not significant, the one for the net recipients is a little smaller, 0.573 , but still highly significant.

The results above show that FUNDEF has a positive impact on education expendi- 
tures for municipalities with a positive net transfer from the fund. For the net contributors there is no clear relationship in above estimation. Hence, the subsequent analysis here will focus on the net recipients.

\subsubsection{FUNDEF effects on other expenditures}

Additionally to a significant impact on educational expenditures, for us to consider FUNDEF as an exogenous variation it is necessary that the fund affect reelection chances only through education expenditures. This cannot be directly tested. Some possibilities of FUNDEF impacting elections through different channels must be ruled out.

Some of these possible channels by which FUNDEF could impact electoral chances of mayors are other municipal revenues and expenditures. Therefore, to use FUNDEF to identify the impact of education expenditures:

1. Other sources of revenue could not have compensated FUNDEF effect;

2. FUNDEF cannot impact public expenditures other than education.

The previous estimation indicated that the net recipients have an impact on their education budgets caused by FUNDEF. For the net contributors there is no clear relationship. Those former municipalities could in principle have the FUNDEF budgetary effect offset by a loss in other off budget-transfers.

To investigate the effect of FUNDEF transfers on other federal and state transfers we estimate the following equations:

$$
\mathbf{F S}: F U N D E F_{i}=\alpha+\beta_{1} X_{i}+\beta_{2} F U N D E F 97_{i}+\epsilon_{i}
$$

$$
\text { SS : Transfer } i=\alpha+\beta_{1} X_{i}+\beta_{2} F U \hat{N D E F} F_{i}+\epsilon_{i}
$$

Where: 
Transfer $=$ the average other non-constitutional federal or state transfer per capita between 1998 and 2000;

The second stage results are shown in the Table 5 below:

Table 5 - 2SLS estimates of FUNDEF's impact on other federal and state transfers

\begin{tabular}{|c|c|c|c|c|}
\hline VARIABLES & $\begin{array}{c}(1) \\
\text { All transfers }\end{array}$ & $\begin{array}{c}(2) \\
\text { Other state transfers }\end{array}$ & $\begin{array}{c}(3) \\
\text { Other federal transfers }\end{array}$ & $\begin{array}{c}(4) \\
\text { Other federal transfers }\end{array}$ \\
\hline Tax revenue & $\begin{array}{c}0.056 \\
(0.043)\end{array}$ & $\begin{array}{c}0.047 \\
(0.037)\end{array}$ & $\begin{array}{c}0.009 \\
(0.012)\end{array}$ & $\begin{array}{c}0.019 \\
(0.012)\end{array}$ \\
\hline State transfers & $\begin{array}{c}0.018 \\
(0.045)\end{array}$ & $\begin{array}{c}0.029^{* *} \\
(0.013)\end{array}$ & $\begin{array}{l}-0.011 \\
(0.042)\end{array}$ & $\begin{array}{l}-0.033 \\
(0.052)\end{array}$ \\
\hline Federal transfers & $\begin{array}{l}0.065^{*} \\
(0.039)\end{array}$ & $\begin{array}{l}0.020^{* *} \\
(0.010)\end{array}$ & $\begin{array}{c}0.045 \\
(0.036)\end{array}$ & $\begin{array}{c}0.067 \\
(0.049)\end{array}$ \\
\hline FUNDEF & $\begin{array}{l}0.137^{*} \\
(0.080)\end{array}$ & $\begin{array}{c}0.007 \\
(0.040)\end{array}$ & $\begin{array}{c}0.130^{* *} \\
(0.063)\end{array}$ & $\begin{array}{l}-0.076 \\
(0.143)\end{array}$ \\
\hline Constant & $\begin{array}{c}66.42 \\
(56.71)\end{array}$ & $\begin{array}{l}19.90^{*} \\
(10.34)\end{array}$ & $\begin{array}{c}46.52 \\
(55.67)\end{array}$ & $\begin{array}{c}102.6 \\
(84.74)\end{array}$ \\
\hline Observations & 973 & 973 & 973 & 584 \\
\hline R-squared & 0.016 & 0.145 & 0.006 & 0.012 \\
\hline Demographic controls & Yes & Yes & Yes & Yes \\
\hline Political controls & Yes & Yes & Yes & Yes \\
\hline
\end{tabular}

As can be seen in the table, FUNDEF has a positive effect on other non-constitutional transfers with a 0.137 coefficient, significant at the $10 \%$ level (column 1). Once we divide them into state and federal transfers there is no significant effect on state transfers (column 2). There is, however a 0.130 effect on federal transfers, significant at the $5 \%$ (column 3 ).

This effect, however, is driven by states that received federal complement on FUNDEF transfers. Once we do the estimation without these states, which are Alagoas, Bahia, Ceará, Maranhão, Pará, Paraíba, Pernambuco and Piauí, the result disappears as can be seen on column 4 . The coefficient on the sub-sample that excludes those states is smaller, negative and not significant.

Another reasonable concern is that the mayors of the net recipient municipalities could have reallocated the budget or used FUNDEF resources for other purposes that could affect reelection chances. 
As for FUNDEF effects on education it is also possible here to make a panel regression with municipality fixed effects to investigate FUNDEF effects on different municipal expenditures. To evaluate whether FUNDEF affected expenditures other than education we estimate the following equations:

$$
\text { FS : FUNDEF } F_{i}=\alpha+\beta_{1} X_{i}+\beta_{2} F U N D E F 97_{i}+\epsilon_{i}
$$

$$
\text { SS : } \text { Expenses }_{i}=\alpha+\beta_{1} X_{i}+\beta_{2} F U \hat{N D E F} F_{i}+\epsilon_{i}
$$

Where:

Expenses $=$ the expenditures on various management functions between 1998 and 2000

The results for the main expenditures are shown in the Table 6 below:

\begin{tabular}{|c|c|c|c|c|}
\hline VARIABLES & $\begin{array}{c}(1) \\
\text { Housing } \\
\end{array}$ & $\begin{array}{c}(2) \\
\text { Health and sanitation }\end{array}$ & $\begin{array}{c}(3) \\
\text { Social security } \\
\end{array}$ & $\begin{array}{c}(4) \\
\text { Transport } \\
\end{array}$ \\
\hline Tax revenue & $\begin{array}{c}0.182^{* * *} \\
(0.062)\end{array}$ & $\begin{array}{c}0.237^{* * *} \\
(0.050)\end{array}$ & $\begin{array}{c}0.0773^{* * *} \\
(0.025)\end{array}$ & $\begin{array}{l}0.0532 \\
(0.033)\end{array}$ \\
\hline State transfers & $\begin{array}{c}0.154^{* * *} \\
(0.029)\end{array}$ & $\begin{array}{c}0.182^{* * *} \\
(0.037)\end{array}$ & $\begin{array}{c}0.063^{* * *} \\
(0.019)\end{array}$ & $\begin{array}{l}0.004 \\
(0.028)\end{array}$ \\
\hline Federal transfers & $\begin{array}{c}0.101^{* * * *} \\
(0.030)\end{array}$ & $\begin{array}{c}0.117^{* * * *} \\
(0.025)\end{array}$ & $\begin{array}{c}0.080^{* * * *} \\
(0.013)\end{array}$ & $\begin{array}{c}0.152^{* * *} \\
(0.023)\end{array}$ \\
\hline FUNDEF & $\begin{array}{c}0.011 \\
(0.072)\end{array}$ & $\begin{array}{l}-0.109 \\
(0.072)\end{array}$ & $\begin{array}{c}0.046 \\
(0.041)\end{array}$ & $\begin{array}{c}-0.150^{* * *} \\
(0.057)\end{array}$ \\
\hline Constant & $\begin{array}{c}-115.779^{* * *} \\
(30.773)\end{array}$ & $\begin{array}{c}-4.697 \\
(28.466)\end{array}$ & $\begin{array}{c}1.587 \\
(14.110)\end{array}$ & $\begin{array}{c}224.412^{* * *} \\
(27.806)\end{array}$ \\
\hline Observations & 973 & 973 & 973 & 973 \\
\hline R-squared & 0.293 & 0.347 & 0.338 & 0.309 \\
\hline Demographic controls & Yes & Yes & Yes & Yes \\
\hline Political controls & Yes & Yes & Yes & Yes \\
\hline
\end{tabular}

Table 6 - 2SLS estimates of FUNDEF's impact on municipal expenditures

As Table 6 above shows, the coefficients of Health and Sanitation, Housing and 
Social security are small and not significant. There is no effect of FUNDEF on those expenditures.

Meanwhile, the Transport coefficient (column 2) is approximately - 0.15 and sgnificant at the $1 \%$ level. This indicates that municipalities with bigger revenues from the fund, all else constant, presented a decrease in this type of spending.

With regards to less representative expenditures results for the same estimation of equation (5.3) are presented in table 13 in the appendix. Apart from communications, there is no significant impact of FUNDEF on other expenditures. As for communications FUNDEF's coefficient is -0.008 and significant at the $5 \%$ level, what indicates that with bigger revenues from the fund, all else constant, this expenditure also presented a decrease.

It is not wholly unexpected that, given the bigger revenues for educational spending, the mayors have reoptimized the municipality expenditures. We cannot disregard this from the analysis. Hence, the results, from now on will consider the first (on education) and second order FUNDEF effects. 


\section{Main Results}

\subsection{FUNDEF effects on reelection}

\subsubsection{Mayor's reelection}

Considering the evidence presented on the previous section we treat the fund transfers, conditional on the total revenues, as a source of exogenous variation in education expenditures. Hence, we proceed to the main estimation, the impact of FUNDEF spending on electoral results of incumbent mayors.

We estimate the impact of FUNDEF, instrumented by the impact of the simulated FUNDEF transfers explained in the data section, on an incumbent mayor chances of reelection. This estimation objectives to address the concerns of unobserved variables or mayors manipulation that could make the fund endogenous. In other words, we estimate the following equations:

FS : FUNDEF_impact ${ }_{i}=\alpha+\beta_{1} X_{i}+\beta_{2} F U N D E F \_$impact_9 $97_{i}+\epsilon_{i}$

$$
\text { SS : } \text { Elected }_{i}=\alpha+\beta_{1} X_{i}+\beta_{2} F U N D E \hat{F} \_ \text {impact }_{i}+\epsilon_{i}
$$

Where:

FUNDEF_97 = the estimated impact variable from the fund in 1997.

Where Elected is the dummy that takes the value of 0 in case of the incumbent mayor having lost the 2000 election and the value of 1 in case he won it. FUNDEF impact is the impact variable of the the fund described in the data section and $X$ is a vector of the following controls.

Governor party and President party are used here to consider the possible effect of political favouring and political support during the elections. It is reasonable to assume 
that a mayor aligned with the state and/or federal governments will have some advantage or disadvantaged in the elections.

Elderly population, Young population and Urban account for demographic features of the municipality. More urbanized cities could have different voting behaviors than smaller and more agricultural ones. The age could affect people attitudes regarding politics especially concerning education.

The results of the second stage estimation are presented in columns 1 to 3 of Table 7 below:

Table 7 - 2SLS estimates of FUNDEF impact instrumented by simulated FUNDEF97 impact effect on an incumbent mayor chances of reelection in 2000

\begin{tabular}{|c|c|c|c|}
\hline VARIABLES & $\begin{array}{c}(1) \\
\text { Elected }\end{array}$ & $\begin{array}{c}(2) \\
\text { Elected }\end{array}$ & $\begin{array}{c}(3) \\
\text { Elected }\end{array}$ \\
\hline FUNDEF impact & $\begin{array}{c}0.081^{* * *} \\
(0.021)\end{array}$ & $\begin{array}{c}0.061^{* * *} \\
(0.023)\end{array}$ & $\begin{array}{c}0.061^{* * *} \\
(0.023)\end{array}$ \\
\hline Tax revenue & $\begin{array}{c}-3.96 \mathrm{e}-05 \\
(0.000287)\end{array}$ & $\begin{array}{c}0.000183 \\
(0.000276)\end{array}$ & $\begin{array}{c}0.000183 \\
(0.000278)\end{array}$ \\
\hline State transfers & $\begin{array}{c}-9.88 \mathrm{e}-05 \\
(0.000350)\end{array}$ & $\begin{array}{c}0.000271 \\
(0.000405)\end{array}$ & $\begin{array}{c}0.000249 \\
(0.000408)\end{array}$ \\
\hline Federal transfers & $\begin{array}{c}0.000325 \\
(0.000251)\end{array}$ & $\begin{array}{l}-7.03 \mathrm{e}-05 \\
(0.000295)\end{array}$ & $\begin{array}{c}-5.27 \mathrm{e}-05 \\
(0.000297)\end{array}$ \\
\hline Young population & & $\begin{array}{c}0.502 \\
(0.655)\end{array}$ & $\begin{array}{c}0.523 \\
(0.658)\end{array}$ \\
\hline Elderly population & & $\begin{array}{c}0.630 \\
(0.973)\end{array}$ & $\begin{array}{c}0.597 \\
(0.977)\end{array}$ \\
\hline Urban & & $\begin{array}{l}-0.193^{* *} \\
(0.0819)\end{array}$ & $\begin{array}{l}-0.198 * * \\
(0.0824)\end{array}$ \\
\hline Governor party & & & $\begin{array}{l}-0.0246 \\
(0.0351)\end{array}$ \\
\hline President party & & & $\begin{array}{c}0.0387 \\
(0.0380)\end{array}$ \\
\hline Constant & $\begin{array}{c}0.477^{* * *} \\
(0.0597)\end{array}$ & $\begin{array}{c}0.366 \\
(0.368)\end{array}$ & $\begin{array}{c}0.361 \\
(0.370)\end{array}$ \\
\hline Observations & 973 & 973 & 973 \\
\hline R-squared & 0.014 & 0.024 & 0.026 \\
\hline Demographic controls & & Yes & Yes \\
\hline Political controls & & No & Yes \\
\hline
\end{tabular}

As shown in column (1) of Table 7 above there is a significant impact of FUNDEF 
transfers on the chances of reelection of a incumbent mayor in a fund's net recipient municipality.

Once we add demographic controls the impact decreases but is still significant. Those results are presented on column (2). Adding the political controls does not change significantly the other coefficients. Those results are presented on column (3).

In addition to the fund transfers, urbanization also has a positive impact on the chances of reelection. Interestingly, there is no significant impact of being of the president's or governor's party.

Table 7 shows that there is a significant impact of FUNDEF on the chances of reelection of a incumbent mayor. The coefficient of FUNDEF impact on column (1) is 0.080 which means that for a municipality that received the double the amount it sent for the fund there was a correspondent 8 percentage points increase in the chances of the mayor getting reelected.

The coefficient of FUNDEF impact on column (3) indicates that for a municipality that received the double of the amount sent to the fund there is an increase of 6.1 percentage points in the incumbent mayor's chances of reelection. It is an impact equivalent to about $11 \%$ of the $55.4 \%$ percent mean chances of an incumbent mayor to get reelected as presented in table 2 .

\subsubsection{Party coalition's reelection}

Additionally to the above estimations, we investigate whether FUNDEF transfers could have affected the party coalition reelection chances. To do so we identify situations where a party coalition for 2000's elections included the incumbent mayor's party, being her the coalition's runner or not. For this situations we run the same regressions as equations (7.1), and (7.2) above. The results are presented in table 8 bellow: 
Table 8 - 2SLS estimates of FUNDEF impact instrumented by simulated FUNDEF97 impact effects on an incumbent party coalition chances of reelection in 2000

\begin{tabular}{|c|c|c|c|}
\hline VARIABLES & $\begin{array}{c}(1) \\
\text { Elected }\end{array}$ & $\begin{array}{c}(2) \\
\text { Elected }\end{array}$ & $\begin{array}{c}(3) \\
\text { Elected }\end{array}$ \\
\hline FUNDEF_impact & $\begin{array}{c}0.074^{* * *} \\
(0.020)\end{array}$ & $\begin{array}{c}0.056^{* * *} \\
(0.022)\end{array}$ & $\begin{array}{c}0.055^{* *} \\
(0.022)\end{array}$ \\
\hline Tax_revenue & $\begin{array}{c}0.000286 \\
(0.000241)\end{array}$ & $\begin{array}{c}0.000487^{* *} \\
(0.000224)\end{array}$ & $\begin{array}{c}0.000490^{* *} \\
(0.000229)\end{array}$ \\
\hline State_transfers & $\begin{array}{l}-0.000239 \\
(0.000313)\end{array}$ & $\begin{array}{c}0.000190 \\
(0.000358)\end{array}$ & $\begin{array}{c}0.000143 \\
(0.000361)\end{array}$ \\
\hline Federal_transfers & $\begin{array}{c}0.000581^{* *} \\
(0.000236)\end{array}$ & $\begin{array}{c}0.000270 \\
(0.000277)\end{array}$ & $\begin{array}{c}0.000247 \\
(0.000276)\end{array}$ \\
\hline Young_population & & $\begin{array}{l}1.068^{*} \\
(0.599)\end{array}$ & $\begin{array}{l}1.038^{*} \\
(0.604)\end{array}$ \\
\hline Elderly_populatiol & & $\begin{array}{l}1.078 \\
(0.890)\end{array}$ & $\begin{array}{l}1.052 \\
(0.892)\end{array}$ \\
\hline Urban & & $\begin{array}{l}-0.0904 \\
(0.078)\end{array}$ & $\begin{array}{l}-0.104 \\
(0.079)\end{array}$ \\
\hline Governo_party & & & $\begin{array}{c}0.007 \\
(0.034)\end{array}$ \\
\hline President_party & & & $\begin{array}{l}0.063^{*} \\
(0.036)\end{array}$ \\
\hline Constant & $\begin{array}{c}0.414^{* * *} \\
(0.055)\end{array}$ & $\begin{array}{l}-0.055 \\
(0.337)\end{array}$ & $\begin{array}{l}-0.038 \\
(0.339)\end{array}$ \\
\hline Observations & 1,164 & 1,164 & 1,164 \\
\hline R-squared & 0.017 & 0.023 & 0.026 \\
\hline
\end{tabular}
at $1 \%$. Robust standard erros in parentheses.

As can be seen in table 8 above, the results for party coalition present little difference related to the ones of incumbent mayors. The coefficient of FUNDEF impact is 0.074 (column 1), compared to 0.081 in table 7 before. Adding demographic and political controls decreases this coefficient to 0.056 and 0.055 respectively, compared to 0.061 for both regarding incumbent mayors as shows table 7 .

The above results mean that for a municipality that receives an amount of resources from FUNDEF correspondent to the double it sent to the fund, the chances of the incumbent mayor being reelected or electing a successor in his party coalition are increased by around 6 percentage points (if taken the coefficient on column 3 of table 8). 


\subsection{FUNDEF effects on school quality}

Given the positive and significant results found in the section above and the second order effects of FUNDEF discussed on the identification section, it is important to discuss the channels by which FUNDEF could have affected incumbent mayors' reelection chances.

One such possible channel is the improvement of school quality. It is difficult to define precisely school quality and there are many possible ways to measure it. Here we use two of those possible measures, which are the ones avaliable in the School Census: teacher's education and school's infrastructure.

To estimate FUNDEF's impact on teachers' education we estimate the following 2SLS equations:

FS : FUNDEF_impact ${ }_{i}=\alpha+\beta_{1} X_{i}+\beta_{2} F U N D E F \_$impact_9 $97_{i}+\epsilon_{i}$

$$
\text { SS : Education_Level }{ }_{i}=\alpha+\beta_{1} X_{i}+\beta_{2} F U N D E \hat{F} \_ \text {impact }_{i}+\epsilon_{i}
$$

Where:

Education_Level is the mean municipality proportion of teachers with that education level (primary, secondary and tertiary) complete or incomplete.

The results are shown in table 9 below:

As shown in Table 9, FUNDEF impact is related to an increase in the proportion of teachers with the lowest and highest levels of education. While the coefficient on secondary

education is negative (column 3), the ones on primary (column 2) and tertiary (column 4) education level are positive, all significant at the $1 \%$ level.

The results indicate that the increases in the number of students per class were followed by a bigger increase in primary and college educated teachers. The increase in teacher with higher education, with a coefficient of 0.27 , was somewhat bigger than for the 
Table 9 - 2SLS estimates of FUNDEF's impact on school quality: class size and teachers education

\begin{tabular}{|c|c|c|c|c|}
\hline VARIABLES & $\begin{array}{c}1) \\
\text { Class Size }\end{array}$ & $\begin{array}{c}(2) \\
\text { Primary }\end{array}$ & $\begin{array}{c}(3) \\
\text { Secondary }\end{array}$ & $\begin{array}{c}(4) \\
\text { Tertiary }\end{array}$ \\
\hline FUNDEF_impact & $\begin{array}{c}1.887^{* * *} \\
(0.128)\end{array}$ & $\begin{array}{c}0.018^{* * *} \\
(0.004)\end{array}$ & $\begin{array}{c}-0.045^{* * *} \\
(0.006)\end{array}$ & $\begin{array}{c}0.027^{* * *} \\
(0.004)\end{array}$ \\
\hline Tax_revenue & $\begin{array}{c}0.00718^{* *} \\
(0.00285)\end{array}$ & $\begin{array}{c}-0.000148^{* * *} \\
(3.95 \mathrm{e}-05)\end{array}$ & $\begin{array}{c}-0.000271^{* * *} \\
(8.83 \mathrm{e}-05)\end{array}$ & $\begin{array}{c}0.000419^{* * *} * \\
(0.000101)\end{array}$ \\
\hline State_transfers & $\begin{array}{c}0.00363^{* * *} \\
(0.000875)\end{array}$ & $\begin{array}{c}-9.59 \mathrm{e}-05^{* * *} \\
(3.34 \mathrm{e}-05)\end{array}$ & $\begin{array}{c}-0.000286^{* * * *} \\
(4.45 \mathrm{e}-05)\end{array}$ & $\begin{array}{c}0.000382^{* * *} \\
(5.44 \mathrm{e}-05)\end{array}$ \\
\hline Federal_transfers & $\begin{array}{c}-0.000701^{* * *} \\
(0.000199)\end{array}$ & $\begin{array}{c}4.50 \mathrm{e}-05^{* * *} \\
(1.03 \mathrm{e}-05)\end{array}$ & $\begin{array}{l}4.13 \mathrm{e}-07 \\
(4.43 \mathrm{e}-06)\end{array}$ & $\begin{array}{c}-4.54 \mathrm{e}-05^{* * *} \\
(1.24 \mathrm{e}-05)\end{array}$ \\
\hline Constant & $\begin{array}{l}-2.136 \\
(1.717)\end{array}$ & $\begin{array}{c}-0.249^{* * *} \\
(0.0540)\end{array}$ & $\begin{array}{l}0.195^{* *} \\
(0.0761)\end{array}$ & $\begin{array}{l}1.054^{* * *} \\
(0.0685)\end{array}$ \\
\hline Observations & 2,862 & 2,862 & 2,862 & 2,862 \\
\hline R-squared & 0.483 & 0.312 & 0.184 & 0.478 \\
\hline Demographic controls & Yes & Yes & Yes & Yes \\
\hline Political controls & Yes & Yes & Yes & Yes \\
\hline
\end{tabular}

teachers with only primary education, with a coefficient of 0.18 . Teachers with higher educational level could provide, at least in principle, a better education.

To estimate FUNDEF's impact on schools infrastructure we estimate the following 2SLS equations:

FS : FUNDEF_impact ${ }_{i}=\alpha+\beta_{1} X_{i}+\beta_{2} F U N D E F \_i m p a c t \_97_{i}+\epsilon_{i}$

SS : Infrastructure_item ${ }_{i}=\alpha+\beta_{1} X_{i}+\beta_{2} F U N D E \hat{F} \_$impact $_{i}+\epsilon_{i}$

Where:

Infrastructure_item is the mean municipality proportion of schools with that infrastructure item (water, energy, sports facility, library and science laboratory) present.

The results are shown in table 10 below:

As Table 10 presents, there is a significant and positive increase in sports facilities, 
Table 10 - 2SLS estimates of FUNDEF's impact on school quality: school infrastructure

\begin{tabular}{|c|c|c|c|c|c|}
\hline VARIABLES & $\begin{array}{c}(1) \\
\text { Water }\end{array}$ & $\begin{array}{c}(2) \\
\text { Energy }\end{array}$ & $\begin{array}{c}(3) \\
\text { Sports facility }\end{array}$ & $\begin{array}{c}(4) \\
\text { Library }\end{array}$ & $\begin{array}{c}(5) \\
\text { Science Laboratory }\end{array}$ \\
\hline FUNDEF_impact & $\begin{array}{l}-0.00549 \\
(0.00650)\end{array}$ & $\begin{array}{l}-0.00692 \\
(0.00624)\end{array}$ & $\begin{array}{l}0.044^{* * *} \\
(0.00502)\end{array}$ & $\begin{array}{l}0.033^{* * *} \\
(0.00524)\end{array}$ & $\begin{array}{l}0.031^{* * *} \\
(0.00320)\end{array}$ \\
\hline Tax_revenue & $\begin{array}{c}0.000627^{* * *} \\
(0.000134)\end{array}$ & $\begin{array}{c}0.000277^{* * *} \\
(7.52 \mathrm{e}-05)\end{array}$ & $\begin{array}{l}0.000218^{*} \\
(0.000131)\end{array}$ & $\begin{array}{c}0.000292^{* *} \\
(0.000139)\end{array}$ & $\begin{array}{c}0.000294^{* * *} \\
(8.22 \mathrm{e}-05)\end{array}$ \\
\hline State_transfers & $\begin{array}{c}0.000399 * * * \\
(6.42 \mathrm{e}-05)\end{array}$ & $\begin{array}{c}0.000313^{* * *} \\
(5.16 \mathrm{e}-05)\end{array}$ & $\begin{array}{c}0.000523^{* * *} \\
(8.48 \mathrm{e}-05)\end{array}$ & $\begin{array}{c}0.000486^{* * *} \\
(7.67 \mathrm{e}-05)\end{array}$ & $\begin{array}{c}0.000239^{* * *} \\
(4.26 \mathrm{e}-05)\end{array}$ \\
\hline Federal_transfers & $\begin{array}{c}-3.89 \mathrm{e}-05^{* * *} \\
(8.09 \mathrm{e}-06)\end{array}$ & $\begin{array}{c}-4.06 \mathrm{e}-05^{* * *} \\
(9.20 \mathrm{e}-06)\end{array}$ & $\begin{array}{c}-4.13 \mathrm{e}-05^{* * *} \\
(1.19 \mathrm{e}-05)\end{array}$ & $\begin{array}{c}-3.59 \mathrm{e}-05^{* * *} \\
(9.92 \mathrm{e}-06)\end{array}$ & $\begin{array}{c}-2.07 \mathrm{e}-05^{* * *} \\
(5.47 \mathrm{e}-06)\end{array}$ \\
\hline Constant & $\begin{array}{c}0.762^{* * *} \\
(0.107)\end{array}$ & $\begin{array}{c}2.485^{* * *} \\
(0.0954)\end{array}$ & $\begin{array}{c}1.704^{* * *} \\
(0.0969)\end{array}$ & $\begin{array}{c}1.827 * * * \\
(0.0946)\end{array}$ & $\begin{array}{c}0.765^{* * *} \\
(0.0651)\end{array}$ \\
\hline Observations & 2,862 & 2,862 & 2,718 & 2,788 & 2,606 \\
\hline R-squared & 0.384 & 0.466 & 0.341 & 0.386 & 0.223 \\
\hline Demographic controls & Yes & Yes & Yes & Yes & \\
\hline Political controls & Yes & Yes & Yes & Yes & \\
\hline
\end{tabular}

libraries and science laboratories. The coefficients are approximately 0.044 on Sports Facilities, 0.033 on Library and 0.31 on Science Laboratory. The results mean that a municipality where FUNDEF impact was 1 observed a correspondent increase of 3.3 and 4.4 percentage points in the number of schools with libraries and sports facilities and an increase of 3.1 percentage points os schools with science laboratories, respectively.

The results above are for the full data avaliable. We calculate the same estimations for the municipalities where the incumbent mayor ran for reelection. The results are presented in tables 11 and 12 below. We also do those estimations for municipalities where the incumbent party coalition ran for reelection and the results are presented in tables 15 and 16 in the appendix.

Table 11 above shows that there is a slight increase in class size for the municipalities where the incumbent mayor ran for reelection. As for the measures of teachers education are not much different from the ones in table 9. Again, there is a significant decrease in the proportion of teachers with secondary education and an increase in teachers with primary and tertiaty education, complete or incomplete. The coefficients on Primary, Secondary and Tertiary are 0.015, -040. and 0.024, all significant at the 1\% level. 
Table 11 - 2SLS estimates of FUNDEF's impact on school quality: school infrastructure - Incumbent mayors of net recipient municipalities

\begin{tabular}{lcccc}
\hline VARIABLES & $(1)$ & $(2)$ & $(3)$ & $(4)$ \\
& Class Size & Primary & Secondary & Tertiary \\
\hline FUNDEF impact & $1.545^{* * *}$ & $0.0185^{* *}$ & $-0.0319^{* * *}$ & $0.0134^{* *}$ \\
& $(0.214)$ & $(0.00825)$ & $(0.0101)$ & $(0.00591)$ \\
Tax revenues & 0.00322 & $1.10 \mathrm{e}-05$ & -0.000125 & 0.000114 \\
& $(0.00264)$ & $(3.39 \mathrm{e}-05)$ & $(8.29 \mathrm{e}-05)$ & $(7.14 \mathrm{e}-05)$ \\
State transfers & $0.00845^{* *}$ & $-0.000297^{* * *}$ & $-0.000643^{* * *}$ & $0.000941^{* * *}$ \\
& $(0.00329)$ & $(0.000103)$ & $(0.000140)$ & $(0.000114)$ \\
Federal transfers & 0.000205 & $0.000162^{*}$ & $4.17 \mathrm{e}-05$ & $-0.000204^{* *}$ \\
& $(0.00253)$ & $(9.46 \mathrm{e}-05)$ & $(0.000124)$ & $(8.80 \mathrm{e}-05)$ \\
Constant & 0.386 & $-0.274^{* * *}$ & $0.299^{* *}$ & $0.975^{* * *}$ \\
\multicolumn{5}{c}{} \\
Observations & $(3.110)$ & $(0.103)$ & $(0.134)$ & $(0.102)$ \\
R-squared & 968 & 968 & 968 & 968 \\
Demographic controls & 0.315 & 0.326 & 0.185 & 0.617 \\
Political controls & Yes & Yes & Yes & Yes \\
Note $-*$ significant at 10\% & Y* significant at $5 \% * * *$ significant at 1\%. Robust standard \\
errors are in parentheses. Demographic controls are urban, elderly proportion, \\
and young proportion. Political controls are president party and governor \\
party.
\end{tabular}

As regards the infrastucture measures the results do not differ much from the previous ones either. There is a highly significant increase in the proportion of schools with Sports facilities, Libraries and Science Laboratories. The coefficients on those variables are respectively $0.036,0.030$ and 0.27 as shown in table 12 below, comparing to $0.044,0.033$ and 0.31 . There is still no significant effect on the provision of water and energy.

The estimations above show that FUNDEF coresponded to an increase in college educated teachers and an improvement in schools' infrastructure. The results suggest that the additional revenue propitiated by FUNDEF was used to improve school quality, as measured by those variables.

Hence, we cannot rule out that the political returns earned by incumbent mayors identified in the previous subsection were related to this improvement in the quality of education. These results agree the ones of Firpo, Pieri and Souza (2012) that found positive electoral effects of improvements in school quality as measured by a public index. 
Table 12 - 2SLS estimates of FUNDEF's impact on school quality: school infrastructure Incumbent mayors of net recipient municipalities

\begin{tabular}{|c|c|c|c|c|c|}
\hline VARIABLES & $\begin{array}{c}(1) \\
\text { Water }\end{array}$ & $\begin{array}{c}(2) \\
\text { Energy }\end{array}$ & $\begin{array}{c}(3) \\
\text { Sports facility }\end{array}$ & $\begin{array}{c}(4) \\
\text { Library }\end{array}$ & $\begin{array}{c}(5) \\
\text { Science Laboratory }\end{array}$ \\
\hline FUNDEF impact & $\begin{array}{c}0.006 \\
(0.00969)\end{array}$ & $\begin{array}{c}-0.007 \\
(0.0103)\end{array}$ & $\begin{array}{l}0.025^{* * *} \\
(0.00743)\end{array}$ & $\begin{array}{c}0.020^{* *} \\
(0.00783)\end{array}$ & $\begin{array}{l}0.023^{* * *} \\
(0.00556)\end{array}$ \\
\hline Tax revenue & $\begin{array}{c}0.000339^{* * *} \\
(0.000123)\end{array}$ & $\begin{array}{c}-0.000125^{*} \\
(6.49 \mathrm{e}-05)\end{array}$ & $\begin{array}{c}-0.000186^{*} \\
(0.000101)\end{array}$ & $\begin{array}{c}2.36 \mathrm{e}-05 \\
(0.000152)\end{array}$ & $\begin{array}{c}0.000126 \\
(0.000103)\end{array}$ \\
\hline State transfers & $\begin{array}{c}0.000877^{* * * *} \\
(0.000186)\end{array}$ & $\begin{array}{c}0.000522^{* * *} \\
(0.000160)\end{array}$ & $\begin{array}{c}0.000923^{* * *} \\
(0.000188)\end{array}$ & $\begin{array}{c}0.000690 * * * \\
(0.000182)\end{array}$ & $\begin{array}{c}0.000470 * * * \\
(0.000130)\end{array}$ \\
\hline Federal transfers & $\begin{array}{c}8.69 \mathrm{e}-05 \\
(0.000159)\end{array}$ & $\begin{array}{c}0.000143 \\
(0.000156)\end{array}$ & $\begin{array}{c}0.000379^{* * *} \\
(0.000146)\end{array}$ & $\begin{array}{c}0.000144 \\
(0.000144)\end{array}$ & $\begin{array}{c}0.000207^{*} \\
(0.000118)\end{array}$ \\
\hline Constant & $\begin{array}{c}1.196^{* * *} \\
(0.170)\end{array}$ & $\begin{array}{c}2.826^{* * *} \\
(0.167)\end{array}$ & $\begin{array}{c}1.794^{* * *} \\
(0.140)\end{array}$ & $\begin{array}{c}1.988^{* * *} \\
(0.139)\end{array}$ & $\begin{array}{c}0.608^{* * *} \\
(0.101)\end{array}$ \\
\hline Observations & 968 & 968 & 951 & 961 & 921 \\
\hline R-squared & 0.514 & 0.552 & 0.508 & 0.549 & 0.319 \\
\hline Demographic controls & Yes & Yes & Yes & Yes & Yes \\
\hline Political controls & Yes & Yes & Yes & Yes & Yes \\
\hline
\end{tabular}

Note $-{ }^{*}$ significant at $10 \%,{ }^{* *}$ significant at $5 \% * * *$ significant at $1 \%$. Robust standard errors are in parentheses. Demographic controls are urban, elderly proportion, and young proportion. Political controls are president party and governor party. 



\section{Concluding Remarks}

This paper provides evidence that Brazilian voters reward incumbent mayors for increased educational spending. FUNDEF provided resources for education expenditures that by their turn increased mayors reelection chances.

The evidence here presented suggests that voters care for education to a considerable extent. Moreover, it is possible that improvements in school quality play a role as a channel through which voters reward education expenditures.

The paper investigates the relationship between education expenditures and chances of reelection of a incumbent mayor. It uses data from Brazilian municipalities between 1998 and 2000 and FUNDEF, a major funding reform, as an exongenous variation in school expenditures.

The first stage estimation shows us that the fund has a great impact on education spending of municipalities that are net recipients from the fund. For each real received from FUNDEF there is a corresponding increase in approximately 0.80 reais in expenditures in education per capita.

Looking at the municipalities more clearly impacted by the transfers of FUNDEF, the net recipients, there is evidence suggesting that education expenditures, via the fund transfers, affected the chances of reelection of incumbent mayors.

For the municipalities that lost resources with the funding reform, the net contributors, there is a smaller and less significant relation between the fund net transfers (in this case negative) and education spending.

The results presented here suggest that for a municipality that received the double of the amount it sent to the fund there is an increase of 6 to 8 percentage points in the mayor's chances of reelection. The voters respond positively to an increase in education spending.

Regarding possible channels by which FUNDEF has affected mayors chances of reelection this work identifies a significant increase in teachers education and school 
infrastructre. The proportion of teachers with tertiary education increased by 2.3 percentage points respectively for a municipality that received the double the amount sent. The proportion of schools with infrastructure items such as a library, sports facility and science laboratory increases by 3.3, 4.4 and 3.1 percentage point for that same municipality respectively. 


\section{Bibliography}

ALESINA, A.; PEROTTI, R. The Political Economy of Budget Deficits. IMF Staff Papers, v. 42, n. 1, p. 1-31, March 1995. Disponível em: <http://ideas.repec.org/a/pal/imfstp/v42y1995i1p1-31.html>. 17

BARBOSA FILHO, F. d. H.; PESSÔA, S. Educação, crescimento e distribuição de renda: a experiência brasileira em perspectiva histórica. In: VELOSO, F. et al. (Ed.). Educação básica no Brasil: construindo o país do futuro. Rio de Janeiro: Elsevier, 2009. 13

BRENDER, A. The effect of fiscal performance on local government election results in Israel: 1989-1998. Journal of Public Economics, v. 87, n. 9-10, p. 2187-2205, September 2003. Disponível em: <http://ideas.repec.org/a/eee/pubeco/v87y2003i9-10p2187-2205.html>. 17

BRENDER, A.; DRAZEN, A. Political budget cycles in new versus established democracies. Journal of Monetary Economics, v. 52, n. 7, p. 1271-1295, October 2005. Disponível em: <http://ideas.repec.org/a/eee/moneco/v52y2005i7p1271-1295.html>. 17, 18

BRENDER, A.; DRAZEN, A. How Do Budget Deficits and Economic Growth Affect Reelection Prospects? Evidence from a Large Panel of Countries. American Economic Review, v. 98, n. 5, p. 2203-20, December 2008. Disponível em: <http://ideas.repec.org/a/aea/aecrev/v98y2008i5p2203-20.html>. 17, 18

ESTEVAN, F. Working Papers, Department of Economics, Public Education Expenditures and Private School Enrollment. 2014. Disponível em: <http://ideas.repec.org/p/spa/wpaper/2014wpecon14.html>. 14, 21, 31

FIRPO, S.; PIERI, R.; SOUZA, A. P. Electoral Impacts of Uncovering Public School Quality: Evidence from Brazilian Municipalities. [S.l.], 2012. Disponível em: $<$ http://ideas.repec.org/p/iza/izadps/dp6524.html>. 19, 48

JANKE, A. Fundos de incentivo ao ensino público e os resultados das eleições municipais. Dissertação (Mestrado) - Escola de Economia de São Paulo - Fundação Getúlio Vargas, São Paulo, 2013. 19, 20

KIMKO, D. D.; HANUSHEK, E. A. Schooling, Labor-Force Quality, and the Growth of Nations. American Economic Review, v. 90, n. 5, p. 1184-1208, December 2000. Disponível em: <http://ideas.repec.org/a/aea/aecrev/v90y2000i5p1184-1208.html>. 13

KOSEC, K. Politics and preschool : the political economy of investment in pre-primary education. [S.l.], 2011. Disponível em: <https://ideas.repec.org/p/wbk/wbrwps/5647.html>. 15,32

KRAMER, G. H. Short-term fluctuations in us voting behavior, 1896-1964. American Political Science Review, Cambridge Univ Press, v. 65, n. 01, p. 131-143, 1971. 17

LITSCHIG, S.; MORRISON, K. Electoral Effects of Fiscal Transfers: Quasi-Experimental Evidence from Local Executive Elections in Brazil, 1982-1988. [S.1.], 2009. 15

MENDES, M.; ROCHA, C. A. A. O que reelege um prefeito? Senado Federal, Consultoria Legislativa, 2004. 19 
MENEGUIN, F. B.; BUGARIN, M. S.; CARVALHO, A. X. d. O que leva um governante à reeleição? Instituto de Pesquisa Econômica Aplicada (Ipea), 2005. 18

MUELLER, J. E. Presidential popularity from truman to johnson. American Political Science Review, Cambridge Univ Press, v. 64, n. 01, p. 18-34, 1970. 17

NAKAGUMA, M. Y. Ciclos políticos e resultados eleitorais: um estudo sobre o comportamento do eleitor brasileiro. Dissertação (Mestrado) — Faculdade de Economia, Administração e Contabilidade - Universidade de São Paulo, São Paulo, 2006. 17

PELTZMAN, S. Voters as Fiscal Conservatives. The Quarterly Journal of Economics, v. 107, n. 2, p. 327-61, May 1992. Disponível em: <http://ideas.repec.org/a/tpr/qjecon/v107y1992i2p327-61.html>. 17, 18

ROMER, P. M. Endogenous Technological Change. Journal of Political Economy, v. 98, n. 5, p. S71-102, October 1990. Disponível em: <http://ideas.repec.org/a/ucp/jpolec/v98y1990i5ps71-102.html>. 13

SAKURAI, S. N. Ciclos políticos nas funções orçamentárias dos municípios brasileiros: uma análise para o período 1990-2005 via dados em painel. Estudos Econômicos (São Paulo), v. 39, n. 1, p. 39-58, 2009. 14, 19

SAKURAI, S. N.; Menezes Filho, N. A. Política fiscal e reeleição nos municípios brasileiros: uma análise via dados em painel para o período 1988-2000. ENCONTRO NACIONAL DE ECONOMIA, v. 35, 2007. 18

TESOURO, Tesouro Nacional. Transferências Constitucionais. 2015. Disponível em: <http://www3.tesouro.gov.br/estados_municipios/transferencias_constitucionais_novosite.asp >. 25

TSE, Tribunal Superior Eleitoral. Repositório de dados eleitorais. 2015. Disponível em: $<$ http://www.tse.jus.br/eleicoes/estatisticas/repositorio-de-dados-eleitorais > . 25

VELOSO, F. 15 anos de avanços na educação no brasil: onde estamos? In: VELOSO, F. et al. (Ed.). Educação básica no Brasil: construindo o país do futuro. Rio de Janeiro: Elsevier, 2009. 13 


\section{Appendix A}

\subsection{FUNDEF's impact on other expenditures}

Table 13 - 2SLS estimates of FUNDEF's impact on municipal expenditures 1998, 1999 and 2000

\begin{tabular}{|c|c|c|c|c|c|c|c|}
\hline VARIABLES & $\begin{array}{c}\text { (1) } \\
\text { Industry and trade }\end{array}$ & $\begin{array}{c}(2) \\
\text { Agriculture }\end{array}$ & $\begin{array}{c}(3) \\
\text { Defense and security }\end{array}$ & $\begin{array}{c}(4) \\
\text { Energy }\end{array}$ & $\begin{array}{c}(5) \\
\text { Regional Development }\end{array}$ & $\begin{array}{c}(6) \\
\text { Communications }\end{array}$ & $\begin{array}{c}(7) \\
\text { Other }\end{array}$ \\
\hline Tax revenue & $\begin{array}{l}0.0967^{*} \\
(0.0509)\end{array}$ & $\begin{array}{l}-0.0133^{*} \\
(0.00779)\end{array}$ & $\begin{array}{c}0.00868 \\
(0.00594)\end{array}$ & $\begin{array}{c}0.0158 \\
(0.0118)\end{array}$ & $\begin{array}{c}0.0115 \\
(0.00714)\end{array}$ & $\begin{array}{c}0.000663 \\
(0.000808)\end{array}$ & $\begin{array}{c}0.00449 \\
(0.00874)\end{array}$ \\
\hline State transfers & $\begin{array}{r}-0.00743 \\
(0.0135)\end{array}$ & $\begin{array}{c}0.00407 \\
(0.00846)\end{array}$ & $\begin{array}{c}0.0240 \\
(0.0198)\end{array}$ & $\begin{array}{l}-0.00625^{*} \\
(0.00325)\end{array}$ & $\begin{array}{l}-0.00548 \\
(0.00568)\end{array}$ & $\begin{array}{c}-0.00386^{* * *} \\
(0.00121)\end{array}$ & $\begin{array}{c}0.0378 \\
(0.0242)\end{array}$ \\
\hline Federal transfers & $\begin{array}{c}0.0564 \\
(0.0353)\end{array}$ & $\begin{array}{c}0.0486^{* * *} \\
(0.00826)\end{array}$ & $\begin{array}{c}0.000236 \\
(0.00332)\end{array}$ & $\begin{array}{l}0.00506^{*} \\
(0.00306)\end{array}$ & $\begin{array}{c}0.00257 \\
(0.00232)\end{array}$ & $\begin{array}{c}0.00475^{* * *} \\
(0.00139)\end{array}$ & $\begin{array}{l}-0.00940 \\
(0.00600)\end{array}$ \\
\hline FUNDEF & $\begin{array}{c}0.0734 \\
(0.0641)\end{array}$ & $\begin{array}{l}-0.0355 \\
(0.0243)\end{array}$ & $\begin{array}{c}0.0288 \\
(0.0255)\end{array}$ & $\begin{array}{l}-0.00557 \\
(0.00951)\end{array}$ & $\begin{array}{c}0.00250 \\
(0.00946)\end{array}$ & $\begin{array}{c}-0.00848^{* *} \\
(0.00377)\end{array}$ & $\begin{array}{c}0.0120 \\
(0.0339)\end{array}$ \\
\hline Constant & $\begin{array}{l}-2.280 \\
(30.64)\end{array}$ & $\begin{array}{c}75.13^{* * *} \\
(12.08)\end{array}$ & $\begin{array}{l}-8.882 \\
(5.780)\end{array}$ & $\begin{array}{c}0.262 \\
(2.680)\end{array}$ & $\begin{array}{c}3.037 \\
(2.988)\end{array}$ & $\begin{array}{c}4.004^{* * *} \\
(1.372)\end{array}$ & $\begin{array}{l}-5.970 \\
(10.10)\end{array}$ \\
\hline Observations & 973 & 973 & 973 & 973 & 973 & 973 & 973 \\
\hline R-squared & 0.177 & 0.219 & 0.117 & 0.085 & 0.037 & 0.058 & 0.041 \\
\hline Demographic controls & Yes & Yes & Yes & Yes & & & \\
\hline Political controls & Yes & Yes & Yes & Yes & & & \\
\hline
\end{tabular}


8.2 FUNDEF impact instrumented by simulated FUNDEF97 impact: First stage

Table 14 - OLS estimates of Impact of FUNDEF97 on FUNDEF

\begin{tabular}{|c|c|c|c|}
\hline VARIABLES & $\begin{array}{c}(1) \\
\text { All municipalities } \\
\end{array}$ & $\begin{array}{c}(2) \\
\text { All municipalities } \\
\end{array}$ & $\begin{array}{c}(3) \\
\text { All municipalities } \\
\end{array}$ \\
\hline FUNDEF 97 & $\begin{array}{c}0.663^{* * *} \\
(0.0163)\end{array}$ & $\begin{array}{c}0.652^{* * *} \\
(0.0169)\end{array}$ & $\begin{array}{c}0.652^{* * *} \\
(0.0169)\end{array}$ \\
\hline Tax revenue & $\begin{array}{l}0.000412^{*} \\
(0.000211)\end{array}$ & $\begin{array}{c}0.000534^{* *} \\
(0.000215)\end{array}$ & $\begin{array}{c}0.000529^{* *} \\
(0.000219)\end{array}$ \\
\hline State transfers & $\begin{array}{c}-0.00161^{* * *} \\
(0.000241)\end{array}$ & $\begin{array}{c}-0.00110^{* * *} \\
(0.000294)\end{array}$ & $\begin{array}{c}-0.00111^{* * *} \\
(0.000293)\end{array}$ \\
\hline Federal transfers & $\begin{array}{c}-0.00110^{* * * *} \\
(0.000184)\end{array}$ & $\begin{array}{c}-0.00120^{* * *} \\
(0.000208)\end{array}$ & $\begin{array}{c}-0.00121^{* * *} \\
(0.000212)\end{array}$ \\
\hline Young population & & $\begin{array}{c}1.750^{* * *} \\
(0.500)\end{array}$ & $\begin{array}{c}1.719^{* * *} \\
(0.503)\end{array}$ \\
\hline Elderly population & & $\begin{array}{c}0.917 \\
(0.768)\end{array}$ & $\begin{array}{c}0.894 \\
(0.773)\end{array}$ \\
\hline Urban & & $\begin{array}{c}0.0368 \\
(0.0616)\end{array}$ & $\begin{array}{c}0.0339 \\
(0.0615)\end{array}$ \\
\hline Governor party & & & $\begin{array}{c}0.0161 \\
(0.0268)\end{array}$ \\
\hline President party & & & $\begin{array}{l}0.00418 \\
(0.0301)\end{array}$ \\
\hline Constant & $\begin{array}{c}0.589^{* * *} \\
(0.0454)\end{array}$ & $\begin{array}{l}-0.268 \\
(0.287)\end{array}$ & $\begin{array}{l}-0.254 \\
(0.288)\end{array}$ \\
\hline Observations & 973 & 973 & 973 \\
\hline R-squared & 0.852 & 0.854 & 0.854 \\
\hline Demographic controls & No & No & No \\
\hline Political controls & No & No & No \\
\hline
\end{tabular}




\subsection{FUNDEF's impact on school quality for municipalities where}

\section{the incumbent party coalition ran for reelection}

Table 15 - 2SLS estimates of FUNDEF's impact on school quality: school infrastructure - Incumbent party coalition

\begin{tabular}{|c|c|c|c|c|}
\hline VARIABLES & $\begin{array}{c}(1) \\
\text { Class Size }\end{array}$ & $\begin{array}{c}(2) \\
\text { Primary }\end{array}$ & $\begin{array}{c}(3) \\
\text { Secondary }\end{array}$ & $\begin{array}{c}(4) \\
\text { Tertiary }\end{array}$ \\
\hline FUNDEF impact & $\begin{array}{c}1.785^{* * *} \\
(0.133)\end{array}$ & $\begin{array}{c}0.0197^{* * *} \\
(0.00498)\end{array}$ & $\begin{array}{c}-0.0425^{* * *} \\
(0.00636)\end{array}$ & $\begin{array}{c}0.0228^{* * *} \\
(0.00441)\end{array}$ \\
\hline Tax revenue & $\begin{array}{c}0.00762^{* *} \\
(0.00313)\end{array}$ & $\begin{array}{c}-0.000103^{* *} \\
(4.04 \mathrm{e}-05)\end{array}$ & $\begin{array}{c}-0.000300^{* * *} \\
(9.91 \mathrm{e}-05)\end{array}$ & $\begin{array}{c}0.000403^{* * *} \\
(0.000112)\end{array}$ \\
\hline State transfers & $\begin{array}{c}0.00469^{* * * *} \\
(0.00100)\end{array}$ & $\begin{array}{l}-4.28 \mathrm{e}-05 \\
(3.37 \mathrm{e}-05)\end{array}$ & $\begin{array}{c}-0.000302^{* * *} \\
(5.12 \mathrm{e}-05)\end{array}$ & $\begin{array}{c}0.000345^{* * *} \\
(5.97 \mathrm{e}-05)\end{array}$ \\
\hline Federal transfers & $\begin{array}{c}-0.000788^{* * *} \\
(0.000197)\end{array}$ & $\begin{array}{c}3.91 \mathrm{e}-05^{* * *} \\
(9.06 \mathrm{e}-06)\end{array}$ & $\begin{array}{c}2.24 \mathrm{e}-06 \\
(4.85 \mathrm{e}-06)\end{array}$ & $\begin{array}{c}-4.14 \mathrm{e}-05^{* * *} \\
(1.14 \mathrm{e}-05)\end{array}$ \\
\hline Constant & $\begin{array}{c}2.197 \\
(1.993)\end{array}$ & $\begin{array}{c}-0.256^{* * *} \\
(0.0630)\end{array}$ & $\begin{array}{l}0.182^{* *} \\
(0.0861)\end{array}$ & $\begin{array}{l}1.074^{* * *} \\
(0.0769)\end{array}$ \\
\hline Observations & 2,201 & 2,201 & 2,201 & 2,201 \\
\hline R-squared & 0.438 & 0.294 & 0.194 & 0.482 \\
\hline Demographic controls & Yes & Yes & Yes & Yes \\
\hline Political controls & Yes & Yes & Yes & Yes \\
\hline
\end{tabular}


Table 16 - 2SLS estimates of FUNDEF's impact on school quality: school infrastructure Incumbent party coalition

\begin{tabular}{lccccc}
\hline & $(1)$ & $(2)$ & $(3)$ & $(4)$ & $(5)$ \\
VARIABLES & Water & Energy & Sports facility & Library & Science Laboratory \\
\hline \multirow{2}{*}{ FUNDEF impact } & -0.00643 & $-0.0129^{*}$ & $0.0361^{* * *}$ & $0.0258^{* * *}$ & $0.0232^{* * *}$ \\
& $(0.00740)$ & $(0.00733)$ & $(0.00590)$ & $(0.00593)$ & $(0.00377)$ \\
Tax revenue & $0.000575^{* * *}$ & $0.000125^{* *}$ & $4.71 \mathrm{e}-05$ & 0.000127 & $0.000194^{* *}$ \\
& $(0.000135)$ & $(6.01 \mathrm{e}-05)$ & $(0.000118)$ & $(0.000140)$ & $(8.78 \mathrm{e}-05)$ \\
State transfers & $0.000383^{* * *}$ & $0.000196^{* * *}$ & $0.000470^{* * *}$ & $0.000314^{* * *}$ & $0.000140^{* * *}$ \\
& $(8.68 \mathrm{e}-05)$ & $(5.76 \mathrm{e}-05)$ & $(0.000108)$ & $(8.53 \mathrm{e}-05)$ & $(4.38 \mathrm{e}-05)$ \\
Federal transfers & $-4.16 \mathrm{e}-05^{* * *}$ & $-2.91 \mathrm{e}-05^{* * *}$ & $-3.64 \mathrm{e}-05^{* * *}$ & $-2.18 \mathrm{e}-05^{* * *}$ & $-1.14 \mathrm{e}-05^{* * *}$ \\
& $(7.60 \mathrm{e}-06)$ & $(7.44 \mathrm{e}-06)$ & $(1.19 \mathrm{e}-05)$ & $(7.88 \mathrm{e}-06)$ & $(4.23 \mathrm{e}-06)$ \\
Constant & $0.973^{* * *}$ & $2.556^{* * *}$ & $1.769^{* * *}$ & $1.864^{* * *}$ & $0.703^{* * *}$ \\
& $(0.136)$ & $(0.118)$ & $(0.123)$ & $(0.114)$ & $(0.0804)$ \\
Observations & & & & 1,749 & 1,658 \\
R-squared & 1,788 & 1,788 & 1,713 & 0.371 & 0.182 \\
Demographic controls & 0.398 & 0.465 & 0.336 & Yes & Yes \\
Political controls & Yes & Yes & Yes & Yes & Yes \\
\hline Nes & Yes & Yes & & \\
\hline
\end{tabular}

Note $-{ }^{*}$ significant at 10\%, ${ }^{* *}$ significant at 5\% *** significant at 1\%. Robust standard errors are in parentheses. Demographic controls are urban, elderly proportion, and young proportion. Political controls are president party and governor party. 